\title{
CLASSICAL REPUBLICANISM AND THE FIFTH AMENDMENT'S “PUBLIC USE" REQUIREMENT
}

\author{
NATHAN AleXANDER SALES
}

[T] he word republic ... signified a government, in which the property of the public, or people, and of every one of them, was secured and protected by law. This idea ... implies, moreover, that the property and liberty of all men, not merely of a majority, should be safe; for the people, or public, comprehends more than a majority, it comprehends all and every individual; and the property of every citizen is a part of the public property, as each citizen is a part of the public, people, or community.

\section{INTRODUCTION}

Throughout two centuries of Takings Clause jurisprudence, American courts have charted an uncertain course between two rival interpretations of the Fifth Amendment's "public use" requirement. ${ }^{2}$ In the early nineteenth century, a New York state court construed "public use" language under the actual-use theory, ${ }^{3}$ according to which a state may take private property only if the entire public is vested with a right to use the seized property interests. ${ }^{4}$ A century

1. 3 JOHN ADAMS, A DEFENCE OF THE CONSTITUTIONS OF GOVERNMENT OF THE UNITED STATES OF AMERICA 160 (1788).

2. The Fifth Amendment provides, in pertinent part: "nor shall private property be taken for public use, without just compensation." U.S. CONST. amend. V. Similar provisions were included in the first state constitutions. See infra Part III.A.

3. See In re Albany St., 11 Wend. 149, 151 (N.Y. Sup. Ct. 1834) ("The constitution, by authorizing the appropriation of private property to public use, impliedly declares, that for any other use, private property shall not be taken from one and applied to the private use of another."). In Albany St., the New York court construed the "public use" requirement of its own constitution, which contained language identical to that of the Fifth Amendment. See N.Y. Const. of 1821, art. 7, $\$ 7$, reprinted in 5 Francis Newton ThORpe, The Federal AND STATE CONSTITUTIONS 2648 (1909) ("[P]rivate property [shall not] be taken for public use, without just compensation.").

4. See William B. Stoebuck, A General Theory of Eminent Domain, 47 WASH. L. REV. 553,589 (1972) (characterizing the actual-use theory as "allow[ing] property interests to be 
and a quarter later, the United States Supreme Court embraced the public-benefit interpretation of the Fifth Amendment, expansively holding that the "public use" requirement is satisfied whenever the power of eminent domain "is being exercised for a public purpose." Under this sweeping construction, the ambit of the "public use" limitation is "coterminous with the scope of a sovereign's police powers." While the "public use" limitation figures in the occasional modern case, ${ }^{7}$ it has been so thoroughly eviscerated by the ascendant public-benefit theory that a leading commentator could quote the Takings Clause as "nor shall private property be taken ... without just compensation" - entirely omitting the phrase "for public use."

Some observers have celebrated the demise of the actual-use test, while others have mourned its passing. ${ }^{9}$ Similarly controversial is whether that interpretation or its rival better reflects the "public use" requirement's original meaning. A minority of commentators have argued that the Constitution's Framers intended a more robust "public use" limitation, ${ }^{10}$ but the weight of scholarly authority maintains

taken only if the subject matter in which they exist, land or things, will be used by the public").

5. Berman v. Parker, 348 U.S. 26, 32 (1954).

6. Hawaii Hous. Auth. v. Midkiff, 467 U.S. 229, 240 (1984); accord Berman, 348 U.S. at 32 (noting that " $[\mathrm{w}] \mathrm{e}$ deal, in other words, with what traditionally has been known as the police power").

7. See, e.g., Southwestern Ill. Dev. Auth. v. National City Envtl., L.L.C., 710 N.E.2d 896, 901, 904 (Ill. App. Ct. 1999) (admitting that "the term 'public use' is flexible in an everchanging society," but holding that state and federal "public use" requirements prohibit "the taking of property from one private party and the immediate transfer of it to another private party, whose interest in the property is solely to earn greater profits"); see also Darryl Van Duch, Eminent Domain Use Curtailed, NAT'L L.J., June 14, 1999, at B4 (describing the Illinois court's ruling as "the first to put the brakes on the power of local governments to use their condemnation powers to spur development in areas not designated as blighted").

8. Bruce A. Ackerman, The Jurisprudence of Just Compensation, 7 ENVTL. L. 509, 510 (1977), quoted in Richard A. EPSTEIn, TAKINGS: Private Property AND the POWER of EMINENT DOMAIN 162 n.6 (1985).

9. Compare, e.g., Comment, The Public Use Limitation on Eminent Domain: An Advance Requiem, 58 YALE L.J. 599, 607 (1949) (attributing the abandonment of strict "public use" enforcement to the twentieth century's "expanding social philosophy"), with EPSTEIN, supra note 8, at 161-62 (lamenting the Supreme Court's "mortal blow" to the "public use" requirement).

10. See, e.g., Donald J. Kochan, "Public Use" and the Independent Judiciary: Condemnation in an Interest-Group Perspective, 3 TEX. REV. L. \& POL. 49, 61 (1998) ("By including 'use'-instead of 'purpose,' 'interest,' 'rationale,' 'reason,' 'benefit,' or some other like term - the Framers chose a narrower and more objective test by which the legitimacy of action must be judged.").

Professor Richard Epstein has devised a similarly narrow account by locating the original meaning of the "public use" requirement in the writings of John Locke. See EPSTEIN, supra note 8, at 16 ("The Lockean system was dominant at the time when the Constitution was adopted. His theory of the state was adopted in Blackstone's Commentaries, and the protection 
that the modern public-benefit test captures the original understanding of the Takings Clause. Historian Buckner Melton maintains that "the original American concept, which appeared in colonial, revolutionary, and early national days, [was] that ... 'public use' actually meant public benefit—of almost any conceivable kind." ${ }^{11}$ Professor Lawrence Berger likewise invokes the "conventional wisdom" that "right after the Revolution the broad view dominated." "The narrower theory, it is supposed, developed in the early nineteenth century out of concern that state legislatures would make too liberal a use of their eminent domain powers to encourage industrialization, in particular the construction of railroads. ${ }^{13}$

of property against its enemies was a central and recurrent feature of the political thought of the day."); see also Bruce W. Burton, Regulatory Takings and the Shape of Things to Come: Harbingers of a Takings Clause Reconstellation, 72 OR. L. REV. 603, 608 (1993) (agreeing that "the framers of the United States Constitution integrated Lockean notions into their new republic"). But see Martin S. Flaherty, History "Lite" in Modern American Constitutionalism, 95 COLUM. L. REV. 523, 556-67 (1995) (sharply criticizing Epstein's historical methodology, particularly his conclusory references to Locke). Under Epstein's Lockean interpretation of "public use," a taking of private property cannot benefit any particular social group to a degree greater than its proportional share of net social resources. See EPSTEIN, supra note 8, at 163-64 (" $[\mathrm{T}]$ he public use requirement should ensure the 'fair' allocation by preventing any group from appropriating more than a pro rata share.").

Professor Epstein's view that Locke principally influenced the founding generation reflects that of earlier generations of commentators, including Daniel Boorstin, Clinton Rossiter, and Edward Corwin. See Daniel J. Boorstin, The Genius of American Politics 78 (1953); Clinton Rossiter, The First American Revolution 224 (1953); Edward S. Corwin, The "Higher Law" Background of American Constitutional Law (pt. 2), 42 HARV. L. REV. 365, 395-404 (1928). Locke, of course, wielded significant influence over the minds of early Americans: one Revolutionary-era pamphleteer grounded an assertion by conclusorily directing his reader to "“[s]ee Locke on government." BERNARD BAILYN, THE IDEOLOGICAL ORIGINS OF THE AMERICAN REVOLUTION 28 n.7 (enlarged ed. 1992) (footnote omitted). Still, contemporary historians generally agree that Locke's influence on the American founders has been greatly exaggerated. See, e.g., id. at 35-36 (emphasizing the influence of eighteenthcentury Whig radicals, especially Trenchard and Gordon, on the American revolutionaries); BARRY Alan SHAin, THE Myth of AMERICAN INDIVIDUALISM: THE Protestant ORIGiNS OF AMERICAN POLITICAL THOUght (1994) (disputing, more generally, the influence of Enlightenment liberalism on early America).

11. Buckner F. Melton, Jr., Eminent Domain, "Public Use," and the Conundrum of Original Intent, 36 NAT. Resources J. 59, 85 (1996).

12. Lawrence Berger, The Public Use Requirement in Eminent Domain, 57 Or. L. Rev. 203, 205 (1978); see also Philip Nichols, Jr., The Meaning of Public Use in the Law of Eminent Domain, 20 B.U. L. REV. 615, 617 (1940) (speculating that "[p]ublic benefit resulting from development of natural resources was long generally regarded as sufficient to establish public use"); Stoebuck, supra note 4, at 595 ("[I]t is doubtful that the draftsmen [of the Fifth Amendment] thought condemnation could be only for the literal use of the public.").

13. See Berger, supra note 12, at 208 (observing that "many courts, perhaps fearful that the public-benefit standard would allow virtually unlimited invasions into the rights of private property, adopted the 'narrow view' that public use meant what it said: actual use or right to 
This Note attempts to provide a richer account of the original understanding ${ }^{14}$ of the "public use" requirement by considering it in the context of classical republicanism, a dominant strand of political philosophy at the time of the American founding. ${ }^{15}$ In contrast to modern liberalism, which aspires to preserve individual rights against societal interference, ${ }^{16}$ the object of republicanism was the pursuit of society's common good. ${ }^{17}$ As a consequence, adherents of republicanism insisted that the state could not deploy its power solely for the benefit of a single person or group of persons. ${ }^{18}$ Given this conception

use of the taken facility by the public"); Melton, supra note 11, at 62 (noting most states' narrow definition of "public use"); Comment, supra note 9, at 602 ("As the exercise of the power became more prevalent, the courts began to seek limitations in the interest of protecting private property."); see also Nichols, supra note 12, at 617-18 (speculating that citizens' fears that a legislature would expropriate their homes and farms in service of industrial development were "not so academic").

14. As Professor Stoebuck has observed, "[o]ne question nobody has much worried about is what the constitutional draftsmen intended concerning public purpose." Stoebuck, supra note 4 , at 591 .

15. Many historians believe that republican ideology was the dominant impulse behind the American Revolution. See, e.g., J.G.A. Pocock, The Machiavellian Moment: Florentine Political Thought and the AtLantic Republican Tradition 506 (1975); Gordon S. WoOd, THE CREATION OF THE AMERICAN RePUblic, 1776-1787, at 53-54 (1969) [hereinafter WOOD, CREATION]. Republican ideology has frequently been used to explore the original understanding of other facets of the Fifth Amendment. See, e.g., Morton J. Horwitz, Republicanism and Liberalism in American Constitutional Thought, 29 WM. \& MARY L. REV. 57, 68 (1987) (agreeing that "the fifth amendment to the Constitution represents a dramatic liberal reversal of the dominant conception of the relationship between the state and individual property holdings"); William Michael Treanor, Note, The Origins and Original Significance of the Just Compensation Clause of the Fifth Amendment, 94 YALE L.J. 694 passim (1985) [hereinafter Treanor, Note] (arguing that the Fifth Amendment's compensation requirement represents a repudiation of the republican view that a disseized property owner was not entitled to compensation as a matter of right); see also William Michael Treanor, The Original Understanding of the Takings Clause and the Political Process, 95 COLUM. L. REV. 782 passim (1995) [hereinafter Treanor, Political Process] (maintaining that the Takings Clause was intended to apply only to physical seizure of land and not to so-called regulatory takings). But see Andrew S. Gold, Regulatory Takings and Original Intent: The Direct Physical Takings Thesis "Goes Too Far", 49 AM. U. L. REV. (forthcoming Dec. 1999) (claiming that the founding generation recognized that government interference with property that fell short of outright appropriation could trigger the Takings Clause's compensation requirement).

16. In the liberal scheme, rights "function as trump cards held by individuals," Ronald Dworkin, Liberalism, in PUBliC AND PRIVATE MORALITY 113, 136 (Stuart Hampshire ed., 1978), that "are not subject to ... the calculus of social interests," JOHN RAWLS, A THEORY OF JUSTICE 4 (1971).

17. See WoOd, CREATION, supra note 15, at 54 ("By 1776 the Revolution came to represent a final attempt ... by many Americans to realize the traditional Commonwealth ideal of a corporate society, in which the common good would be the only objective of government.").

18. See id. ("To eighteenth-century American and European radicals alike, living in a world of monarchies, it seemed only too obvious that the great deficiency of existing governments was precisely their sacrificing of the public good to the private greed of small ruling 
of politics, one should expect early American law to have forbidden takings of private property that did not vest the entire public with a right of use. After all, legislative acts designed to benefit only a portion of the public, to the detriment of other members of the body politic, would run afoul of the first principle of republican theory. In fact the opposite occurred, as legislatures routinely authorized takings now regarded as having benefited a discrete segment of the public at the expense of their neighbors. ${ }^{19}$

This Note attempts to explain that apparent contradiction by looking to the republican notion that "the public" possessed a single, homogenous set of interests. Although the modern eye perceives that early exercises of eminent domain benefited only a portion of society, such takings were in fact understood to benefit the entire public. This is so because early Americans generally believed that the members of the public shared the same core interests, and a benefit to one could therefore be thought of as a benefit to all. ${ }^{20}$ Republican ideology thus enabled contemporaries to regard public-benefit takings as actual-use takings. In other words, while simple historical practices suggest that what is today known as the public-benefit interpretation reflects the Takings Clause's original meaning, the ideology informing those practices actually demanded that a taking of private property satisfy the actual-use test. By focusing on these practices and not the ideas that animated them, modern originalist accounts of the "public use" requirement are incomplete.

In Part I of this Note, the actual-use and public-benefit interpretations are more fully examined. Part II considers the essential features of republican theory, with particular attention paid to republican visions of property and the post-Revolutionary influence of republicanism. Part III surveys early historical practices, discussing uses of the eminent domain power under the "public use" requirements of various state constitutions. Finally, Part IV argues that republican ideology allowed early Americans to regard public-benefit

groups.”).

19. The best-known examples of such takings are the Mill Acts, which generally authorized riparians to construct mill dams and thus effectively to condemn the land of neighbors whose holdings became flooded. See infra Part III.B. Early state governments also allowed landowners to make use of their neighbors' property by constructing purely private roads. See infra Part III.C.

20. See Stanley N. Katz, Thomas Jefferson and the Right to Property in Revolutionary America, 19 J.L. \& ECON. 467, 481 (1976) ("At the heart of this faith was the assumption that the people, especially when set against their rulers, were a homogeneous body whose 'interests when candidly considered are one." (quoting WOOD, CREATION, supra note 15, at 57-58)). 
takings as actual-use takings, and suggests that contemporary originalist accounts of "public use" are lacking to the extent that they fail to account for that requirement's intellectual underpinnings.

\section{DEFINING THE TERMS}

The Fifth Amendment's "public use" language has generated two principal interpretations, conventionally known as the actual-use and public-benefit theories. Despite their differences, both accounts share two crucial assumptions. First, they agree that the "public use" requirement dictates whether a taking is permissible in the first instance, not whether the government is required to furnish compensation for a particular class of taking. Second, and as a consequence, both interpretations agree that the Clause disempowers the state from taking property for nonpublic uses. In other words, the government may take private property only if it will be put to a public use, and if it furnishes compensation. ${ }^{21}$ Both assumptions are textually problematic. The Fifth Amendment does not expressly forbid takings that are for other than a public use; it only requires that those takings that are for a public use be compensated. ${ }^{22}$ They are, nevertheless, core premises. ${ }^{23}$

21. The two interpretations are furthermore alike in that they often overlap. A taking that satisfies the actual-use test will always satisfy the public-benefit test, because the public's right of access to condemned property is itself a public benefit.

22. See Berger, supra note 12, at 205 (acknowledging that the Fifth Amendment "do[es] not expressly forbid governmental takings of property for a private use"); Stoebuck, supra note 4, at 591 (emphasizing that "[t]he phrase does not read 'shall not be taken except for public use and not without just compensation"” and musing that "[n]obody seems to have worried about that either"); see also 2A JULIUS L. SACKMAN, NichOLS ON EMINENT DOMAIN § 7.01[5], at 720 to 7-21 (rev. 3d ed. 1999) [hereinafter NiCHOLS ON EMINENT DOMAIN] (observing that state constitutions did not require compensation for takings of property for private use).

23. Professor Jed Rubenfeld has recently offered an alternative interpretation in which he maintains that the Clause does not serve as an absolute bar on takings that are for other than a public use. See Jed Rubenfeld, Usings, 102 YALE L.J. 1077, 1079 (1993). Professor Rubenfeld argues that the "public use" requirement is not a threshold test, the failure of which will render a government taking unconstitutional. See id. at 1079. Instead, it merely designates which class of takings - those where private property is conscripted and put to state use - must be compensated. See id. at 1080. On this interpretation, for example, the government would be permitted to take private property and redistribute it to other private parties, and would not be required to provide compensation.

Insofar as it rests on historical grounds, see id. at 1120-21 (interpreting the 1780 Massachusetts constitution's "public use" language); but see id. at 1122 ("I am far from being an intentionalist in constitutional interpretation ...."), Professor Rubenfeld's proposal appears unsound. First, the founding generation believed that the Fifth Amendment required compensation regardless of whether the taken property was actually put to use. Professor Treanor has highlighted the widespread belief among early Americans that for the federal gov- 


\section{A. The Actual-Use Test}

Commonly described as "narrow," ${ }^{24}$ the actual-use interpretation appears to be well supported by the plain meaning of the Fifth Amendment's text. After all, "a public use exists when the public uses something." 25 On this view, the state may take private property only in those circumstances where all members of the public will actually use the taken property. ${ }^{26}$ To determine whether a taking satisfies the "public use" limitation, one focuses not on the government's general objective in seizing the property, but rather on the specific

ernment to abolish slavery without compensating the slaves' former masters would violate the Takings Clause - even though the slaves would not be "used" by the state. See Treanor, Political Process, supra note 15, at 839 \& n.292 (emphasizing that the original understanding of the Takings Clause "is at odds with Professor Jed Rubenfeld's recent suggestion"). For instance, James Madison instructed an abolitionist that any emancipation proposals would "require a provision in the plan for compensating a loss of what [the former slaveowners] held as property guarantied by the laws, and recognised by the Constitution." Letter from James Madison to Robert Evans (June 15, 1819), reprinted in THE MIND OF THE FOUNDER: SOURCES OF THE Political Thought of JAMEs MAdison 397, 399 (Marvin Meyers ed., 1973). Because founding-era Americans thought that the government owed compensation even if it did not affirmatively use the property it took, they could not have seen the "public use" requirement as merely limiting the necessity of compensation to a particular category of takings.

Additionally, Rubenfeld overstates the significance of the 1780 Massachusetts constitution's "public use" language, which reads:

[N]o part of the property of any individual can, with justice, be taken from him, or applied to public uses, without his own consent, or that of the representative body of the people.... And whenever the public exigencies require that the property of any individual should be appropriated to public uses, he shall receive a reasonable compensation therefor.

MASs. CONST. of 1780, pt. 1, art. X, reprinted in 3 THORPE, supra note 3, at 1891. Rubenfeld argues that, while the second clause specifies that private property taken "to public uses" does require compensation, the first clause permits certain uncompensated takings. See Rubenfeld, supra, at 1120. It is doubtful, however, that the two clauses were designed to express different takings requirements. Instead, as the second sentence unexpectedly was added during floor debates, the existence of two separate clauses proves nothing more than sloppy draftsmanship. See Melton, supra note 11, at 76-77; Stoebuck, supra note 4, at 592-93.

24. See Berger, supra note 12, at 205; Nichols, supra note 12, at 624; Comment, supra note 9 , at 603 .

25. Comment, supra note 9, at 603; see also Roger Clegg, Reclaiming the Text of the Takings Clause, 46 S.C. L. REV. 531, 537 (1995) ("Even if it made no sense to limit the clause to takings 'for public use' . . that is the way the clause reads."); Stoebuck, supra note 4, at 590 (implying that the "use by the public" test is supported by the "literal sense" of the Clause).

26. See Stoebuck, supra note 4, at 589 (suggesting that under the "purest, and mostly fabeled [sic] form" of the actual-use test, property rights could be seized "only if the subject matter in which they exist, land or things, will be used by the public"); Annotation, Public Benefit or Convenience as Distinguished from Use by the Public as Ground for the Exercise of the Power of Eminent Domain, 54 A.L.R. 7, 8 (1928) ("[T]he trend of authority is away from any general definition of the term 'public use' as synonymous with public benefit, and to restrict it ... to the meaning of use by the public."). 
use to which the property will be put. ${ }^{27}$ The test is also satisfied if the public does not in fact use, but only retains a right to use, the seized property. ${ }^{28}$ The actual-use test thus comprises two elements: universal access and equal access. That is, all members of the public must have access to the seized property, and no member may have more right of access than any other.

Another sense in which a taking may be said to satisfy the actual-use test is when each member of the public equally benefits from the taking. The equal-benefit formulation of actual use considers the above elements at a higher level of generality: universal benefit and equality of benefit. ${ }^{30}$ This formulation resembles the public-benefit test insofar as it identifies benefit, rather than use, as the criterion of public use. However, it retains the essential elements of the actualuse test: universal and equal distribution of the benefit. This Note will use these two senses of "actual use" interchangeably. A taking satisfies the actual-use test either if the entire public enjoys a right of access to the condemned property, or if all members of the public benefit equally from the taking. For example, a government satisfies the actual-use test when it condemns private farmland for a municipal air terminal, open to all, or when it condemns the farm for a military airstrip that is closed to the general public, but the use of which for national defense produces a benefit redounding equally to all citizens.

Perhaps the best-known instance of actual-use analysis appears in a concurring opinion to Bloodgood v. Mohawk \& Hudson R.R.

27. See Nichols, supra note 12 , at 626-27 (describing the actual-use theory as requiring one to "disregard the ultimate purpose of the taking and consider only the intended use of the particular land").

28. See Berger, supra note 12, at 205 (describing the actual-use interpretation as requiring either the public's "actual use or right to use of the condemned property"); Comment, supra note 9, at 603 ("The indirect contribution to the prosperity of the entire community ... was not sufficient to justify the exercise of eminent domain. It was necessary that the public possess a 'right' to use the facility or service for which the property was desired."); see also EPSTEIN, supra note 8 , at 168 ("So long as all individuals have the right to use the facility on these terms, then the public use requirement is satisfied, even if all individuals cannot simultaneously use it.").

29. When the actual-use test is reduced to these two elements, it resembles Professor Epstein's proposed interpretation of "public use." See EPSTEIN, supra note 8, at 166-69. The "nondiscrimination" principle in Epstein's account, like the requirement of equal access, is "designed to ensure that no single individual or small group of individuals ... is able to capture the entire surplus to the exclusion of others." Id. at 168 .

30. This level of generality introduces the problem of calculating equality of benefit: must the benefits be equal in absolute terms, or equal with respect to one's proportional share of net social resources? This problem is considered in EPSTEIN, supra note 8, at 162-66. 
Co. ${ }^{31}$ In that 1837 case, the New York Court for the Correction of Errors ${ }^{32}$ upheld the state legislature's power to authorize railroad companies to condemn private lands for the construction of new lines, ${ }^{33}$ but decided against the railroad for not having paid compensation before seizing the plaintiff's land. ${ }^{34}$ In his separate concurrence, Senator Tracy rejected the majority's holding that the legislature constitutionally could transfer property from one private holder to another. Instead, he reasoned, takings that did not vest the public with a right of access were contrary to the text of the state constitution's "public use" requirement, ${ }^{35}$ since the "natural import of the term "public use" connotes "public possession and occupation." 36 Senator Tracy accordingly concluded that the legislature could not authorize takings that merely produced a benefit to the public, as they were "repugnant to the language and object of the constitutional provision.",37

\section{B. The Public-Benefit Test}

Owing to the "wondrous elasticity" of the concept of "the public good," 38 the requirements of the public-benefit test are rather more vague. Justly characterized as "broad," 39 public-benefit theory finds that a taking of private property satisfies the "public use" requirement when it results in some benefit to some portion of the public. ${ }^{40}$

31. 18 Wend. 9 (N.Y. 1837).

32. The Court for the Correction of Errors, New York's highest tribunal at the time, was "a complicated amalgam of the state's Chancellor, the Justices of the Supreme Court, and the 32 members of the state senate." Paul Finkelman, Sorting Out Prigg v. Pennsylvania, 24 RUTGERS L.J. 605, 625 n.100 (1993).

33. See Bloodgood, 18 Wend. at 78 ("[T]he legislature of this state has the constitutional power and right to authorize the taking of private property for the purpose of making rail roads or other public improvements of the like nature ....").

34. See id. ("[B]y the true construction of the defendants' charter or act of incorporation, they were not authorized to take and appropriate the plaintiff's land to their use ... until his damages were appraised and paid ....").

35. New York's 1821 constitution provided that "private property [shall not] be taken for public use, without just compensation." N.Y. CONST. of 1821, art. 7, 7 , reprinted in 5 THORPE, supra note 3 , at 2648.

36. Bloodgood, 18 Wend. at 60 (Tracy, Sen., concurring).

37. Id. at 62 (Tracy, Sen., concurring).

38. Comment, supra note 9 , at 601.

39. See Berger, supra note 12, at 205; Comment, supra note 9, at 608.

40. See Berger, supra note 12, at 205 (explaining that the public-benefit theory "means advantage or benefit to the public"); Annotation, supra note 26, at 11 (contending that under public-benefit analysis, "public use" is "synonymous with public benefit, convenience, or advantage"). What portion of the public must benefit for the taking to qualify as a public benefit is unclear. Berger believes that a taking produces a public benefit only if it "benefits large 
Because "public use" is synonymous with "public advantage" in this test's classic formulation, the means of satisfying the "public use" test are as varied as the types of public advantages. ${ }^{41}$ Because every action of a democratic government presumably is designed to produce some public good, the central question in public-benefit analysis is not to which specific use the property will be put, but whether the government has the constitutional power to pursue the object for which it is taken. ${ }^{42}$

Under public-benefit theory, even a state-initiated transfer of property between private parties will pass "public use" muster, so long as it results in some benefit to the public. In Hawaii Housing Authority v. Midkiff, ${ }^{43}$ the United States Supreme Court confronted Hawaii's policy of forcing wealthy landowners to sell plots of land to their tenants. ${ }^{44}$ The Court upheld the state's redistribution scheme because it found a reasonable basis for Hawaii's determination that redistributing land would produce the public benefit of "reduc[ing]

numbers of persons," Berger, supra note 12 , at 225 , but he provides no guidance for determining how large is large enough. See also 2A NICHOLS ON EMINENT DOMAIN, supra note 22, § 7.02 [3], at 7-28 (requiring that the taking benefit "any considerable number of inhabitants of a state or community" (emphasis added)).

41. Nichols's description of the public-benefit test testifies to its breadth:

Any eminent domain action which tends to enlarge resources, increase industrial energies, or promote the productive power of any considerable number of inhabitants of a state or community manifestly contributes to the general welfare and prosperity of the whole community and thus constitutes a valid public use.

2A Nichols On EMINENT Domain, supra note 22, § 7.02[3], at 7-28 to 7-29.

42. Writing in 1940, Professor Nichols portentously observed that "if the narrow doctrine is rejected, the question of public use becomes one, not of the intended utilization of the particular land taken, but of the constitutional power of the sovereign to engage in the project for which it is taken." Nichols, supra note 12 , at 634 . The Supreme Court would later echo that language in Berman v. Parker, 348 U.S. 26, 33 (1954): "Once the object is within the authority of Congress, the right to realize it through the exercise of eminent domain is clear."

As several commentators have emphasized, this loose analysis merely duplicates the requirement that a taking must satisfy the rational basis test under the Fifth Amendment's Due Process Clause. See EPSTEIN, supra note 8, at 162 (stressing that the "public purpose" test "suggests that the court, in its search for a 'rational basis,' can supply a purpose the legislature itself missed"); Rubenfeld, supra note 23, at 1079 ("[T]he so-called 'public-use requirement' is simply duplicative of the legitimate-state-interest test that every deprivation of property must satisfy under the Due Process and Equal Protection Clauses."); cf. Clegg, supra note 25, at 537 ("Indeed, if the only requirement were that the federal government be acting pursuant to a legitimate purpose, then no phrase would be needed at all, since that requirement is implicit throughout the Constitution."); Kochan, supra note 10, at 62 ("Such constructs would leave the Takings Clause empty, for the legitimacy threshold would be so low that nothing could be barred. Any action could subjectively be seen to provide some benefit or interest to society.").

43. 467 U.S. 229 (1984).

44. See id. at 233-34. 
the perceived social and economic evils of a land oligopoly." ${ }^{45}$ Michigan's Supreme Court reached a similar result in Poletown Neighborhood Council v. City of Detroit. ${ }^{46}$ In that case, the court held that the Michigan constitution's "public use" requirement did not bar the city of Detroit from condemning a neighborhood inhabited by persons of Polish ethnicity to facilitate the construction of a privately owned General Motors factory. ${ }^{47}$ The court acknowledged that the case involved a transfer of property from one private party to another, ${ }^{48}$ but concluded that the project nevertheless constituted a public use since the factory would result in the benefits of new jobs and economic growth. ${ }^{49}$

\section{ClasSiCAL REPUBLICAN THEORY}

The era of the American Revolution has been described as "the high point of the American recrudescence of the classical republican tradition of political thought.. ${ }^{, 50}$ During the final decades of the eighteenth century, republican theory-a body of thought culled primarily from English revolutionary and Italian Renaissance sources ${ }^{51}-$ dominated the American political landscape. ${ }^{52}$ It "offered Americans

45. Id. at $241-42$

46. 304 N.W.2d 455 (Mich. 1981) (per curiam).

47. See id. at $459-60$.

48. See id. at 457 (acknowledging that the state of Michigan had "condemn[ed] property for transfer to a private corporation").

49. See id. at 459 (citing "substantial evidence of the severe economic conditions facing the residents of the city and state, the need for new industrial development to revitalize local industries, [and] the economic boost the proposed project would provide").

50. Gregory S. Alexander, Time and Property in the American Republican Legal Culture, 66 N.Y.U. L. REV. 273, 274 (1991).

51. Historians dispute the precise sources to which American republicanism is indebted. Gordon Wood believes that republicanism was derived almost exclusively from eighteenthcentury English Whig radicalism. See WoOd, Creation, supra note 15, passim. Although Bernard Bailyn denies that republicanism per se motivated the American Revolution, see Bernard Bailyn, Faces of Revolution: Personalities and Themes in the Struggle FOR AMERICAN INDEPENDENCE 227 (1990), he similarly emphasizes the role of English oppositionist thought in bringing about American independence, see BAILYN, supra note 10, at 3454. J.G.A. Pocock, however, traces republicanism to the political philosophers of the Italian Renaissance. See PoCOCK, supra note 15, at 506. Morton Horwitz has also called for a broader understanding of American republicanism's roots and emphasizes the role of the Scottish Enlightenment and French republican thought. See Horwitz, supra note 15, at 70-71.

52. Historians generally agree that republicanism was the motivating force behind the American revolution. Professor Treanor has described republicanism as "the reigning ideology of 1776," Treanor, Note, supra note 15, at 699, and Professor Pocock observed that "[n]ot all Americans were schooled in this tradition, but there was (it would almost appear) no alternative tradition in which to be schooled," Pocock, supra note 15, at 507. 
a universe of discourse .... [that] established a framework for discussion; certain generally accepted ideas and goals existed, and a special language was shared." ${ }^{53}$ The central features of republican theory-an assumption that the public shared an homogenous set of interests, and an insistence that political power be deployed for the benefit of all citizens - powerfully shaped early conceptions of property and continued to influence American law well after the Revolution.

\section{A. The Public, the Common Good, and Virtue}

As its etymology suggests, republican theory held that the object of government is to advance the res publica, or common good. John Adams derived the word "republican" thus: "The word res, every one knows, signified, in the Roman language, wealth, riches, property; the word publicus ... signified public, common, belonging to the people; res publica therefore was publica res, the wealth, riches, or property of the people." ${ }^{54}$ Pennsylvania's 1776 constitution described the object of political action similarly: "[G]overnment is, or ought to be, instituted for the common benefit, protection and security of the people, nation or community; and not for the particular emolument or advantage of any single man, family, or sett [sic] of men, who are a part only of that community ...." In Indeed, "[n]o phrase except 'liberty' was invoked more often by the Revolutionaries than 'the public good." " individual citizens desired, but as a substantive moral fixture that transcended individual interests. ${ }^{57}$ John Adams echoed this idea when

Republicanism was an independent body of political theory, not simply the basis of colonial opposition to British rule. Gordon Wood argues that "[r]epublicanism meant more for Americans than simply the elimination of a king and the institution of an elective system." WoOd, CREATION, supra note 15, at 47. Rather, the Revolution was seen by many Americans as "a final attempt ... to realize the traditional Commonwealth ideal of a corporate society, in which the common good would be the only objective of government." Id. at 54 .

53. Robert E. Shalhope, Republicanism and Early American Historiography, 39 WM. \& MARY Q. 334, 342 (1982).

54. 3 ADAMS, supra note 1, at 160; see also WOOD, CREATION, supra note 15, at 55 ("By definition [republican government] had no other end than the welfare of the people: res publica, the public affairs, or the public good."); Mortimer Sellers, Republicanism, Liberalism, and the Law, 86 KY. L.J. 1, 3 \& n.9 (1997) (noting that the "central meaning of republican government since Cicero has been legislation for the 'res publica' or common good of the people").

55. PA. CONST. of 1776, Declaration of Rights, art. V, reprinted in 5 THORPE, supra note 3, at 3082, 3082-83.

56. WOOD, CREATION, supra note 15 , at 55.

57. See id. at 58 ("The people were in fact a single organic piece...."); Alexander, supra 
he wrote that "the people, or public, comprehends more than a majority, it comprehends all and every individual.,"58

Accordingly, all members of "the public"-which comprised the common people, but not the aristocracy or Crown ${ }^{59}$ - were expected to practice, and the state was expected to encourage, "public virtue": the subordination of individual interests to the greater good. Professor Gordon Wood argues that this "sacrifice of individual interests to the greater good of the whole formed the essence of republicanism," and, indeed, "[t]he eighteenth-century mind was thoroughly convinced that a popularly based government "cannot be supported without Virtue." "'61 Republicans' emphasis on virtue helps explain why George Washington was so esteemed by his countrymen. More than any other American, the great Revolutionary general was believed to have sacrificed his own interests for the sake of the fledgling nation. ${ }^{62}$

note 50, at 280 ("[S]ociety [was] a homogenous body whose members were organically linked together."); Horwitz, supra note 15, at 68-69 ("The republican tradition promotes the concept of an autonomous public interest, whereas the liberal ideal holds that the public interest is either simply procedural or the sum of private interests.").

58. 3 ADAMS, supra note 1 , at 160.

59. See WoOd, Creation, supra note 15, at 18 (arguing that republicans conceived of society as "divided into estates or orders, with the people constituting a single unitary estate alongside the nobility and the Crown").

60. Id. at 53; see also Alexander, supra note 50, at 280 (identifying "the idea that private 'interests' both could and should be subordinated to the common welfare of the polity" as "[t]he core" of eighteenth-century republican thought); Katz, supra note 20, at 483 ("This notion of public virtue was at the core of republican political thought...."); Treanor, Political Process, supra note 15, at 821 ("Republican thinkers ... see the end of the state as the promotion of the common good and of virtue.").

Commentators do not universally accept Professor Wood's definition of "public virtue" ("[t]his willingness of the individual to sacrifice his private interests for the good of the community," WOOD, CREATION, supra note 15, at 68). Forrest McDonald argues that, in addition to the subordination of self-interest, republican virtue "entailed firmness, courage, endurance, industry, frugal living [and] strength ...." Forrest MCDOnALD, Novus ORdo SEClORuM: THE INTELlectual ORIGINS OF THE CONSTITUTION 70 (1985). J.G.A. Pocock disagrees with Wood's emphasis on self-denial, and argues that the essence of republican virtue was individual participation in public affairs. See POCOCK, supra note 15, at 73-76. The difference between Wood's and Pocock's interpretations of public virtue is more fully explored in Daniel T. Rodgers, Republicanism: The Career of a Concept, 79 J. AM. HIst. 11, 19-21 (1992), and in Treanor, Political Process, supra note 15, at 820 n.195.

61. WoOd, Creation, supra note 15, at 68 (footnote omitted). For republicans, public virtue was an essential principle of social organization. As republicanism held that it was illegitimate for social order coercively to be imposed on the people by their rulers, it was essential that "obedience must be internalized." Katz, supra note 20, at 482. Republicans' insistence on the necessity of public virtue thus followed from their belief that "in such a state, order, if there was to be any, must come from below." WOOD, CREATION, supra note 15, at 66 .

62. See MCDONALD, supra note 60, at 191-99. The widespread perception that Washington was virtuous perhaps ensured that John Marshall would settle on a career in public service. 
The republican insistence that the state advance the public good, not private individual interests, was made intelligible by an assumption that all members of the public shared identical interests. ${ }^{63}$ Indeed, the belief that the public possessed an homogenous set of interests was "[a]t the heart of this faith." ${ }^{64}$ As republicans conceived of them, "[t]he people were in fact a single organic piece ... with a unitary concern that was the only legitimate objective of governmental policy." ${ }^{65}$ Republicans readily perceived the existence of diverging interests among social orders; they recognized that the commoners had different interests from the aristocracy, whose interests in turn were dissimilar to the Crown's. ${ }^{66}$ But they did not believe that different persons within the same social order had opposing interests. ${ }^{67}$

Marshall, who by 1798 had completed his tenure as minister to France, had twice declined thenPresident John Adams's offers to nominate him to the Supreme Court, citing his desire to return to private practice. After a private meeting with the former president, Marshall consented to stand for Congress in the election of 1798. Washington informed Marshall of his "most sacred duty" to run for the House of Representatives, and silenced his objections by pointing out that he himself had sacrificed much in service of his country. Marshall assented, later admitting that "[m]y resolution yielded to this representation." DAVID LOTH, CHIEF JUSTICE: JoHN MARSHALL AND THE GROWTH OF THE REPUBLIC 146 (1949).

63. See WoOD, CREATION, supra note 15, at 57-58 ("What made the Whig conception of politics and the republican emphasis on collective welfare of the people comprehensible was the assumption that the people, especially when set against their rulers, were a homogeneous body whose 'interests when candidly considered are one."' (footnote omitted)).

64. Katz, supra note 20, at 481.

65. WoOd, Creation, supra note 15, at 58; see also Alexander, supra note 50, at 280 (identifying the republican belief that the public was "a homogenous body whose members were organically linked together").

An uneasy tension existed between republicanism's insistence that individuals subordinate their individual interests to the common good, and its assumption that all members of the public naturally share the same interests. If the latter were true, then the former imperative would have been unnecessary. Thus, the basis of Thomas Jefferson's opposition to emancipating slaves without colonizing them - that the daily interaction of whites and Blacks would produce factions - both confirms the republican emphasis on pursuing the public good and undermines the republican assumption that the public inherently had uniform interests. Jefferson believed that "[d]eep rooted prejudices entertained by the whites; ten thousand recollections, by the blacks, of the injuries they have sustained; new provocations; . . . will divide us into parties, and produce convulsions which will probably never end but in the extermination of the one or the other race." Thomas JefFerson, Notes on the State of Virginia 138 (William Peden ed., Univ. of N.C. Press 1954) (1787) (emphasis added).

66. See WoOd, CREAtion, supra note 15 , at 18 (identifying the "medieval" notion that society was "divided into estates or orders, with the people constituting a single unitary estate alongside the nobility and the Crown"); Sellers, supra note 54, at 3 (emphasizing that "the mixed republican structure of government balances magistrates against the senate and people (or their representatives) to preserve the liberty of the whole").

67. See WOOD, CREATION, supra note 15, at 57-58 (explaining republicans' "assumption that the people, especially when set against their rulers, were a homogeneous body" (emphasis added)). 
Republicans' near-unbridled confidence in popularly elected legislatures ${ }^{68}$ followed directly from their belief in the public's uniformity of interests. Indeed, the ideal of an organic society was actualized in representative assemblies. "'It is in their legislatures,' declared a Rhode Islander... 'that the members of a commonwealth are united and combined together into one coherent, living body. This is the soul that gives form, life and unity to the commonwealth." ${ }^{, 69}$ For Edmund Burke, the institution of Parliament was the objective representation of English society; social classes and geographic diversities were there unified into a cohesive whole. Parliament, he instructed, was not

a congress of ambassadors from different and hostile interests; which interests each must maintain, as an agent and advocate, against other agents and advocates; but parliament is a deliberative assembly of one nation, with one interest, that of the whole; where, not local purposes, not local prejudices, ought to guide, but the general good, resulting from the general reason of the whole. ${ }^{70}$

Early Americans' faith in legislatures was not, however, blind. Contemporaries were all too aware that legislators were susceptible to "corruption"-meaning, in part, the tendency to pursue individual self-interest rather than the public good. ${ }^{71}$ In order to ensure the parity of interests between citizen and representative that was necessary

68. See MCDONALD, supra note 60 , at 160 (commenting that Revolutionary-era state constitutions "in practice vested virtually unlimited powers in popularly elected legislatures").

69. Providence Gazette, Apr. 3, 1779, quoted in WoOd, Creation, supra note 15, at 162. Locke's Second Treatise on Civil Government was apparently much in the mind of our pamphleteer, who quoted it nearly verbatim and without attribution: "[I]t is in their legislative, that the members of a commonwealth are united, and combined together into one coherent living body. This is the soul that gives form, life, and unity to the commonwealth." JOHN Locke, The Second Treatise on Civil Government § 212, at 115 (Prometheus Books, 1986) (1690).

70. EDMUnd Burke, Speech to the Electors of Bristol (1774), in BURKE's SPEECHES AND LETTERS ON AMERICAN AFFAIRS 73 (Everyman's Library ed., 1908).

71. See Pauline Maier, The Old Revolutionaries: Political lives in the Age of SAMUEL ADAMS 209-10 (1980) (observing that prominent members of the founding generation, including Samuel Adams, John Carroll of Carrollton, and Richard Henry Lee, feared the influence of corruption on politics); SHAIN, supra note 10, at 34 ("Corruption was understood as 'a failure to devote one's energies to the common good, and a corresponding tendency to place one's own interests above those of the community." (quoting 1 QUENTIN SKINNER, THE Foundations of Modern Political Thought 164 (1978))). "Corruption" was also understood to comprehend self-indulgence in "luxuries," or an extravagant lifestyle. See BAILYN, supra note 10, at 130-38 (remarking that such corruption was often believed to derive from the unprecedented gains in wealth available from trade with the East). 
for effective representation, ${ }^{72}$ states therefore typically provided for frequent elections. ${ }^{73}$

Such confidence in legislatures paralleled a deep suspicion of the royal magistracy and of the aristocracy. ${ }^{74}$ Republicans feared that these two estates corruptly would deploy their power to advance their own interests to the detriment of those of the general public. ${ }^{75}$ Not only would that aggrandizement destabilize the balance of power between the three political classes that was essential to a viable political order, it would also contradict the charge that government ad-

72. Americans retained the basic assumption underlying the concept of representation (the idea "that certain people from the society, if their interests were identical with the rest, could justly speak for the whole," WoOD, CREATION, supra note 15 , at 176) even as they rejected the British application of "virtual representation," according to which Americans' interests were represented in Parliament even if individual colonists had not actually voted. Representation was possible because of the "'intimate connexion of interest' among electors, nonelectors, and representatives ...." Id. at 179 (footnote omitted).

73. American republicans adhered to the Radical Whig maxim that "where ANNUAL ELECTION ends, TYRANNY begins." H. TREVOR COLBOURN, THE LAMP OF EXPERIENCE: Whig History and the InTellectual Origins of the American Revolution 191 (1965) (footnote omitted). Accordingly, all states except South Carolina provided for annual elections. See WoOd, CrEATION, supra note 15, at 166; see also MCDONALD, supra note 60, at 160 (observing that, for republicans, "the only necessary check upon the legislatures was frequent elections by the people").

74. Although the king's political-patronage network was much weaker in the American colonies than in England itself, nevertheless "for many Americans the crown's manipulation of offices and patronage remained pervasive and powerful enough to arouse their continual exasperation and anxiety." GORDON S. WOOD, THE RADICALISM OF THE AMERICAN REVOLUTION 79 (1991) [hereinafter WOOD, RADICALISM]. Colonists feared that by appointing favorites to positions of authority, the Crown and its agents would wield undue influence over local politics. See id. at 77-80. Royal governors were especially distrusted. The first states' constitutions therefore sharply limited the powers of their governors: most were elected by the legislatures, see WOOD, CREATION, supra note 15, at 139, and "it was almost a foregone conclusion that the new governors would be prohibited from sharing in the lawmaking authority," id. at 141 .

Republican hostility to hereditary aristocracy was so great that members of the Society of Cincinnati, an organization comprising former officers of the Continental Army, were condemned at the end of the Revolution. See Lyon's Case, 15 F. Cas. 1183, 1186 (C.C.D. Vt. 1798) (No. 8,646) (noticing the "fierce denunciations of the peerage of the Cincinnati" in the Jeffersonian press). Americans feared that the Cincinnati, who were entitled to pass membership to their eldest sons, would come to resemble the lately repudiated English aristocracy and undermine republican government. See ANDREW BURSTEIN, THE INNER JEFFERSON: PORTRAIT OF A GRIEVING OPTIMIST 221 (1995) (discussing Jefferson's belief that hereditary societies "tended to reserve 'privilege and prerogative' to themselves, while oppressing the natural rights of the people" (footnote omitted)).

75. See WoOd, Creation, supra note 15, at 54 ("To eighteenth-century American and European radicals alike, living in a world of monarchies, it seemed only too obvious that the great deficiency of existing governments was precisely their sacrificing of the public good to the private greed of small ruling groups."). 
vance the common good, not private interests. ${ }^{76}$ Later years would see a similar suspicion directed toward legislatures. Americans became convinced that their representatives were just as likely as the Crown and aristocracy to become corrupted and to pursue their individual interests at the expense of the people's. ${ }^{77}$

\section{B. Republicanism and Property}

Early Americans' emphasis on public virtue had significant implications for their notions of private property. Republican theory exhibited a "profoundly ambivalent stance toward private property." "78 It was necessary for participation in civic affairs, since only property holders were thought to be sufficiently independent from the influence of other men to discern the public good, but it was also subject to the demands of that public good. In addition, republican attitudes shaped takings law by defining the vastly different powers to seize private property enjoyed by the king and by legislative assemblies.

1. Republican Rationales for Private Property. According to republican theory, private property (most particularly land ${ }^{79}$ ) was important as a necessary condition of participation in popular government. $^{80}$ Only property holders were thought sufficiently

76. See BAILYN, supra note 10, at 130 (describing the American belief that "the balance of the [English] constitution had been thrown off by a gluttonous ministry usurping the prerogatives of the crown and systematically corrupting the independence of the Commons").

77. Robert Morris of Pennsylvania was singled out by an anonymous pamphleteer as one who had subordinated the public good to his own interests. Morris was accused of converting the Bank of North America "to his own and creatures emolument, and by the aid thereof, controuling the credit of the state, and dictating the measures of government." PHILADELPHIA INDEPENDENT GAZETTEER, Jan. 2, 1787, reprinted in 15 THE DOCUMENTARY HISTORY OF THE RATIFICATION OF THE CONSTITUTION 231, 234 (John P. Kaminski \& Gaspare J. Saladino eds., 1984) [hereinafter DOCUMENTARY HISTORY]; see also RICHARD B. MORRIS, THE FORGING OF THE UNION, 1781-1789, at 40-42 (1987) (recounting Morris's dealings with the Bank and the public's reaction)

78. Treanor, Political Process, supra note 15, at 821 \& n.197.

79. Thomas Jefferson, for example, believed that land, not just "property rights in the abstract," was "critical for the development of this country." Katz, supra note 20, at 473.

80. See MCDONALD, supra note 60, at 74 ("In this scheme of thought, virtue, independence, liberty, and the ownership of unencumbered real property were inextricably bound together."); Katz, supra note 20, at 470 (observing that republicans "did not defend property as an end in itself but rather as one of the bases of republican government"); Treanor, Political Process, supra note 15, at 821 (commenting that "republicans treasured private property" because it "provid[ed] the individual with the autonomy that was a prerequisite for full participation in the polity"). 
independent - that is, unlikely to be influenced by private interests or allegiances - to be trusted to advance the public good. ${ }^{81}$ Those who did not possess sufficient property could not be trusted to pursue the good of the whole; instead, they would blindly follow the will of other men or, worse still, seek to gratify their own material wants and desires. ${ }^{82}$ John Adams bluntly queried:

[Is] it not ... true, that men in general, in every society, who are wholly destitute of property, are ... too dependent upon other men to have a will of their own?... Such is the frailty of the human heart, that very few men who have no property, have any judgment of their own. ${ }^{83}$

This view helps explain the widespread colonial property requirements for voting and holding office. For instance, New Yorkers could not vote in colonial assembly elections unless they owned a freehold worth at least fifty pounds (or that produced an annual income between forty and fifty shillings), and Virginia similarly conditioned participation on one hundred acres of unsettled land or twenty-five acres of improved land. ${ }^{84}$

81. Two eighteenth-century English Whigs captured the point nicely: "To live securely, happily, and independently, is the end and effect of liberty .... and real or fancied necessity alone makes men the servants, followers, and creatures of one another. And therefore... property is the best support of that independency, so passionately desired by all men." 1 JOHN Trenchard \& ThOMAs Gordon, CATO's LeTters: Or, EsSAYS ON LiberTy, Civil AND RELIGIOUS, AND OTHER IMPORTANT SUBJECTS 483 (Ronald Hamowy ed., Liberty Fund 1995) (1721); see also J.G.A. Pocock, Virtue, COMMERCE, AND History 103 (1985) ("The citizen possessed property in order to be autonomous and autonomy was necessary for him to develop virtue or goodness as an actor within the political, social, and natural realm or order.").

82. See Alexander, supra note 50, at 287 ("On this view, individuals who did not own property were forced to devote their attention to providing for their own personal welfare, exposing them to corrupting influences and distracting them from the public good."); see also JaCk P. Greene, Pursuits of Happiness: The Social Development of EARly Modern BRITISH COLONIES AND THE FORMATION OF AMERICAN CULTURE 186-87, 195-96 (1988) (distinguishing between independents, or those who owned property, and dependents, or those whose property was controlled by others); MCDONALD, supra note 60, at 71 (commenting that under republicanism "no member of the public could be dependent upon any other and still be reckoned a member of the public").

83. Letter from John Adams to James Sullivan (May 26, 1776), in 9 THE WORKS OF JOHN ADAMs 376 (Charles Francis Adams ed., 1854). Thomas Jefferson echoed the same theme: "Dependence begets subservience and venality, suffocates the germ of virtue, and prepares fit tools for the designs of ambition." JEFFERSON, supra note 65, at 165.

84. See Chilton Williamson, American SufFrage: From Property to DEMOCRACY, 1760-1860, at 12-15 (1960). Property requirements persisted into the era of American independence, and were enshrined in many early state constitutions, often in their bills of rights. See, e.g., PA. Const. of 1776, Declaration of Rights, art. VII, reprinted in 5 THORPE, supra note 3, at 3083 ("That all elections ought to be free; and that all free men hav- 
Restrictions such as these might appear to the modern observer as self-interested attempts to preserve the political power of elite landowners, but many republicans actually favored wide distribution of property as a means of promoting broad participation in government. $^{85}$ Jefferson propounded this idea in his Notes on the State of Virginia, where he argued that widespread landholding was beneficial because it encouraged independence and prevented corruption:

Those who labour in the earth are the chosen people of God, if ever he had a chosen people, whose breasts he has made his peculiar deposit for substantial and genuine virtue.... Corruption of morals in the mass of cultivators is a phaenomenon of which no age nor nation has furnished an example. ${ }^{86}$

Similarly, Jefferson urged that Virginia abolish the fee tail estate in land to expand property rights and thereby to increase the number of independent landholders:

To annul this privilege .... no violence was necessary, no deprivation of natural right, but rather an enlargement of it by a repeal of the law. For this would authorize the present holder to divide the

ing a sufficient evident common interest with, and attachment to the community, have a right to elect officers, or to be elected into office.”); VA. CONST. of 1776, Bill of Rights, § 6, reprinted in 7 THORPE, supra note 3, at 3813 ("[T] hat all men, having sufficient evidence of permanent common interest with, and attachment to, the community, have the right of suffrage...."). Blackstone explained the rationale for such requirements in language foreshadowing Adams's and Jefferson's. "The true reason," he wrote, "of requiring any qualification, with regard to property, in voters, is to exclude such persons as are in so mean a situation that they are esteemed to have no will of their own." 1 WiLliam BlackSTONE, COMMENTARIES *165.

85. See Katz, supra note 20, at 483 ("[W]idespread landholding and the predominance of farming in the economy might well be seen as essential to republicanism, as it was precisely this sort of individual industry which produced the virtue upon which the republican state depended."). Although leading republicans favored widespread landholding, they seldom advocated state confiscation of wealth and redistribution. Thomas Jefferson initially favored redistribution but came to oppose it on prudentialist grounds. Writing to James Madison from France, Jefferson admitted that "an equal division of property is impracticable." "But," he continued, "the consequences of this enormous inequality producing so much misery to the bulk of mankind, legislators cannot invent too many devices for subdividing property, only taking care to let their subdivisions go hand in hand with the natural affections of the human mind." Letter from Thomas Jefferson to James Madison (Oct. 28, 1785), reprinted in 8 THE PAPERS OF THOMAS JEFFERSON 681, 682 (Julian P. Boyd ed., 1953) [hereinafter JEFFERSON PAPERS].

86. JEFFERSON, supra note 65, at 164-65. Noah Webster agreed: "But in an agricultural country, a general possession of land in fee simple, may be rendered perpetual, and the inequalities introduced by commerce, are too fluctuating to endanger government." NOAH Webster, An EXAMINATION INTO THE LEAding PRINCIPLES OF THE Federal Constitution Proposed by the Late Convention Held at Philadelphia (1787), reprinted in PAmphlets on the Constitution of the United States 25, 59 (Paul Leicester Ford ed., 1888). 
property among his children equally, as his affections were divided; and would place them, by natural generation on the level of their fellow citizens. ${ }^{87}$

2. The Influence of Republicanism on Takings Law. Beyond shaping Americans' general conceptions of property, republican theory also powerfully shaped takings law by defining the strikingly different powers of popularly elected legislatures and of the Crown to seize private property. As we have seen, republicans believed that legislative assemblies, thought to share the people's interest, generally advanced the public good. ${ }^{88}$ Conversely, they viewed with suspicion the political power of the Crown and aristocracy, which were feared prone to serving their own interests at the expense of the public's. ${ }^{89}$ Hence legislatures enjoyed wide latitude to take private property, while the Crown's power was charily scrutinized.

In England, Parliament had broad discretion to seize real property by power of eminent domain and frequently used it. The practice probably dates to 1427 , when Parliament enacted a statute that expropriated private land for the construction of sewers and gutters. ${ }^{90} \mathrm{~A}$ clearer example of eminent domain is found in 1539, when Parliament authorized the city of Exeter to improve a river with the stipulation that injured landowners be duly compensated. ${ }^{11}$ As a general rule, Parliament was required to furnish the owner compensation upon its condemnation of private property. ${ }^{92}$

Colonial, Revolutionary, and early national-era legislators wielded similarly expansive authority to conscript the property of private persons, although early American assemblies seldom used that power. ${ }^{93}$ When they did, assemblies invoked eminent domain to build public buildings and public works, to inspect tobacco, to lay out

87. ThOMAS JEFFERSON, AUtOBIOGRAPHy 1743-1790, reprinted in 1 THE Writings of ThOMAS JEFFERSON 1, 49-50 (Paul Leicester Ford ed., 1892).

88. See supra notes $68-73$ and accompanying text.

89. See supra notes 74-77 and accompanying text.

90. See Stoebuck, supra note 4, at 565 (citing 6 Hen. 6, ch. 5 (1427) (Eng.)).

91. See 31 Hen. 8, ch. 4 (1539) (Eng.) ("[They] shall pay to the owners and farmers of so much ground as they shall dig, the rate of twenty years purchase, or so much as shall be ajudged by the justices of assise in the county of Devon.").

92. See Berger, supra note 12, at 204. But see Treanor, Political Process, supra note 15, at $786 \mathrm{n} .15$ (citing authorities proposing that Parliament was not required to pay compensation).

93. See Nichols, supra note 12, at 617 ("Only a few situations existed, in the primitive America of that day, where eminent domain was felt to be needed."). 
towns, and, most frequently, to construct public roads. ${ }^{94}$ As early as 1639, Massachusetts authorized local officials to lay out their towns' roads, ${ }^{95}$ and the 1669 Fundamental Constitution of Carolina, used as a model but never adopted, similarly provided for the construction of public highways. ${ }^{96}$ Although after gaining independence the first states almost invariably paid compensation to the private landowners whose holdings were conscripted, ${ }^{97}$ they were generally under no constitutional obligation to do so. ${ }^{98}$

94. See James W. Ely, Jr., "That Due Satisfaction May Be Made:" The Fifth Amendment and the Origins of the Compensation Principle, 36 AM. J. LEGAL HIST. 1, 4-13 (1992). Although road building was the most common use of eminent domain, extensive construction was unnecessary as early Americans often traveled along preexisting trails blazed by American Indians. See MCDONALD, supra note 60, at 23-24.

95. See Acts Respecting Highways and Private Ways § 1, in ThE CHARTERS AND General LaWs of THE COLONY AND Province OF MASSACHUSETTS BAY 126-27 (1814).

96. See Fundamental Constitution of CAROlina art. 44 (1669), reprinted in 2 THE Earliest Printed Laws of North Carolina, 1669-1751, at 142 (John D. Cushing ed., 1977) [hereinafter CUSHING'S NORTH CAROLINA LAws].

97. Massachusetts, New Hampshire, North Carolina, Rhode Island, and Vermont awarded compensation without regard to whether the land was improved or unimproved, while Delaware, New York, Pennsylvania, and (probably) South Carolina provided compensation only when the land was improved. See Ely, supra note 94, at 7-10. But see Stoebuck, supra note 4, at 582 ("Apparently the normal, if not universal, pattern was to pay only for improved or enclosed land.").

These latter states may have justified their failure to indemnify disseized landowners on the grounds that the resulting increase in value of a given landowner's adjacent property was itself just compensation. See Berger, supra note 12, at 204 (stating that for roads built across unimproved lands, "the argument was made that the owner's total property values were increased by the road, and so no damage was sustained."); Ely, supra note 94, at 11 (observing that colonists "may well have reasoned that the economic advantages of a highway would more than offset the loss of a small amount of unimproved land by the owner"); Stoebuck, supra note 4, at 583 ("In effect, the colonials made an 'irrebuttable presumption'; that is, a rule of law by the fictionalizing process, that a new road would always give more value than the unenclosed land it occupied had."). But see Treanor, Note, supra note 15, at 695-96 n.6 (disagreeing with Stoebuck and arguing that colonial road statutes did not presume that the road was itself compensation).

98. Of the first state constitutions, only those of Vermont and Massachusetts required the state to compensate property owners when the state seized their property. See MASs. CONST. of 1780, pt. 1, art. X, reprinted in 3 THORPE, supra note 3, at 1891; VT. CONST. of 1777, ch. I, art. II, reprinted in 6 THORPE, supra note 3, at 3740. Pennsylvania's constitution also mentioned eminent domain, but it required nothing more than that "no part of a man's property can be justly taken from him, or applied to public uses, without his consent, or that of his legal representatives [that is, the legislature]...." PA. CONST. of 1776, Declaration of Rights, art. VIII, reprinted in 5 THORPE, supra note 3, at 3083 (emphasis added).

Professor Treanor has explained the absence of compensation requirements as the result of republican ideology, which required that individual interests, including property rights, be subordinated to the public good. See Treanor, Political Process, supra note 15, at 785 (arguing that "the compensation requirement was not generally recognized at the time of the framing of the Fifth Amendment"); Treanor, Note, supra note 15, at 695 ("Neither colonial statutes nor 
Several possible explanations exist as to why the compensation requirement was not enshrined in early state constitutions. First, the notion that the government necessarily owed compensation when it took real property was so fundamental that it may have been thought unnecessary to express it. ${ }^{99}$ The absence of compensation requirements would thus be symmetrical with the lack of express constitutional grants of eminent domain power. Just as state constitutions did not enumerate the power of eminent domain because it was deemed an inherent attribute of sovereignty, ${ }^{100}$ neither did they provide for compensation, which was assumed due as a matter of natural law. Second, early Americans were not accustomed to relying on constitutions, charters, or other foundational legal documents to protect the people's rights. ${ }^{101}$ Instead, popularly elected legislatures were deemed

the first state constitutions recognized a right to receive compensation when the government took property from an individual."). Treanor's claim, which is primarily grounded in the absence of just compensation clauses in the first state constitutions, has been widely accepted by legal scholars and historians alike. See Clegg, supra note 25, at 538 (concluding that the Takings Clause "was not a simple codification of rights that had existed already"); Horwitz, supra note 15, at 68 ("As Treanor has shown, ... the surprising absence of just compensation clauses in postrevolutionary state constitutions was based on powerful republican communitarian conceptions of property."); Michael W. McConnell, Contract Rights and Property Rights: A Case Study in the Relationship Between Individual Liberties and Constitutional Structure, 76 CAL. L. REV. 267, 281-82 (1988) (acknowledging that colonies regularly paid compensation, but arguing that payments were "made pursuant to specific statutory authorization or judicial decision, and not as a matter of constitutional right").

99. See Ely, supra note 94, at 4 ("Far from representing an innovation, the takings clause simply codified a longstanding constitutional principle upholding the right of compensation for property taken for public use."); Stoebuck, supra note 4, at 555 (emphasizing that "the [eminent domain] principles we have come to think of as constitutional existed ... independently of written constitutions"); Comment, supra note 9, at 600 (claiming that the compensation requirement "was so generally accepted as a principle of 'natural law' that a number of early state constitutions omitted it").

Blackstone in particular recognized that Parliament was obligated to furnish compensation when it took private property: "But how does it interpose and compel? Not by absolutely stripping the subject of his property in an arbitrary manner; but by giving him a full indemnification and equivalent for the injury thereby sustained." 1 BLACKSTONE, supra note 84 , at $* 135$.

100. See Vanhorne's Lessee v. Dorrance, 2 U.S. (2 Dall.) 304, 310-11 (C.C.D. Pa. 1795) (acknowledging that the power of eminent domain "has been urged from the nature of the social compact"); Stoebuck, supra note 4, at 559 (observing that eighteenth-century civil law scholars, including Pufendorf, Bynkershoek, and Vattel, generally agreed that sovereign governments inherently possess the power of eminent domain).

101. States, of course, did not have constitutions, in the modern sense of the word, until 1775. The idea of protecting rights by resorting to a foundational legal document, derived ultimately from the will of the people themselves, was so revolutionary that one historian traces American independence to the moment the Continental Congress encouraged the colonies to draft constitutions. See WoOd, CREATION, supra note 15, at 132 ("There in the May 15 resolution was the real declaration of independence, from which the measures of early July could be 
competent to do so. ${ }^{102}$ Finally, the British had not abused their eminent domain power, and Americans therefore saw no need expressly to restrict that of their representatives. ${ }^{103}$

In contrast to the broad powers wielded by Parliament and colonial legislatures, the king possessed only limited authority to take private property. The Crown's circumscribed takings authority derived from its prerogative powers, which included the powers to provide for the national defense, ensure dominion of the seas, enact laws and issue proclamations, charter trading societies, dispense justice, and provide for the royal household. ${ }^{104}$ When the king took property for these purposes, he generally was not required to furnish compensation. ${ }^{105}$ Magna Carta, however, required the Crown to indemnify subjects when it took their grain, ${ }^{106}$ and, by long-established custom, the king was required to pay the full value of property taken to supply his household. ${ }^{107}$

By far the most significant difference between legislatures' and the Crown's takings powers was that the king was never permitted to seize title to land. ${ }^{108}$ The king could take derelict lands, ${ }^{109}$ presumably on the theory that no landowner was thereby dispossessed. He could also make use of natural resources, such as metals and gravel, located on private property, and enter onto private property to construct or

but derivations.")

102. See supra notes 68-73 and accompanying text.

103. See Stoebuck, supra note 4, at 594 (remarking that "while the British were scoundrels in a thousand ways, they never abused eminent domain"). None of the most significant Revolutionary documents, such as the Declaration of Independence or the Articles of Association forming the Continental Congress, complained that the British had abused the power of eminent domain. See id. at 594 \& n.145.

104. A comprehensive list of the Crown's prerogatives may be found in 6 JOHN COMYNS, A Digest OF THE LAws OF ENGLAND 28-76 (Samuel Rose ed., 4th ed. London, A. Strahan 1800).

105. See Stoebuck, supra note 4, at 564-65.

106. Article 28 of Magna Carta prohibited the Crown from "tak[ing] corn or other provisions from any one without immediately tendering money therefor ...." Magna Carta ch. 28 (1215), reprinted in William SHARP MCKECHNIE, MAGNA CARTA: A COMMENTARY ON THE GREAT CHARTER OF KING JOHN 329 (2d ed. 1914).

107. See Stoebuck, supra note 4, at 563.

108. See 1 BLACKSTONE, supra note 84 , at $* 135$ (stating that only Parliament was permitted to condemn land); Berger, supra note 12, at 204 (describing the king's power to "make use of but not take ownership of private land"); Stoebuck, supra note 4, at 564 ("One thing the king could never do under his prerogative powers was to take a possessory estate in land.”).

109. See 6 COMYNS, supra note 104, § D 61, at 59:

So, land, derelict by the sea, belongs to the king by his prerogative; for when the dominion and soil of the British sea belong to him, the derelict land, by consequence, shall be his. ... So, where a large tract of land is derelict suddenly; though the lord of the manor claims where there is a gradual accession to land adjacent. 
maintain lighthouses, drains, and sewers. ${ }^{110}$ But the prohibition on seizing title to a subject's real property seems to have been strictly observed. ${ }^{111}$ Because the Crown could never take land, and was not required to furnish compensation when it seized personalty, its prerogative powers to commandeer property were not powers of eminent domain. ${ }^{112}$

Professor Stoebuck has argued that the reason legislatures alone could take title to private land was related to the nature of representative government: under the principles of representation, the people themselves consented to the taking. ${ }^{113}$ Our survey of republican ideology furnishes a more complete explanation, based on the republican recognition that the king and commons had diverging interests. Because each instance of the king's seizure of personalty derived from his prerogative powers, it would on that account be in the service of a public enterprise, such as national defense or the administration of justice. By contrast, the king's ownership of land in fee simple would not have furthered a public good, and could have been only for his own personal benefit. He was therefore permitted the former and refused the latter. Restrictions on the Crown's authority thus reflected the republican notion that the power to take property should

110. See Case of the Isle of Ely, 77 Eng. Rep. 1139, 1139 (K.B. 1610) ("[T]he King ought of right to ... provide that his subjects have their passage through the realm by bridges and highways in safety ...."); 6 COMYNS, supra note 104, § D 42, at 52 ("The king cannot take gravel in the land of a subject without his consent, for repairing of his palace. Nor, timber, \&c. Nor, to make a wall, bridge, \&c. about his royal house.").

111. See, e.g., Isle of Ely, 77 Eng. Rep. at 1140 (holding that the king could not authorize commissioners to condemn land for new sewers, even though Parliament had the authority to do so).

112. See Stoebuck, supra note 4, at 564-65 (arguing that the king's prerogative powers differed from eminent domain, as he was neither permitted to take land nor required to pay compensation for taken personal property).

113. See id. at 568; see also infra notes 143-46 and accompanying text (discussing the substitution of legislative consent for that of the landowner in early state takings clauses). Professor Stoebuck's answer is unsatisfactory because it anachronistically associates Parliament with the legislative function and the Crown with the executive function. This analysis projects the modern notion of "separation of powers" onto a world where the branches of government reflected divisions of class more than of function. Parliament, for example, was not simply a legislative body; it also exercised judicial powers. The practice of representative assemblies serving as judicial organs persisted in America, as early legislatures regularly sat as courts and issued their judgments in the form of laws. See LAwrence M. Friedman, A History OF AMERICAN LAw 39-46 (2d ed. 1985) (describing the blurred lines between legislative and judicial powers in colonial America); WOOD, RADICALISM, supra note 74, at 81 ("The modern distinctions between legislation and adjudication were far from clear."). Even today the Massachusetts legislature is called the "General Court." See Gordon S. Wood, Comment, in ANTONIN SCALIA, A MATTER of INTERPRETATION: FedERAL COURTS AND THE LAW 49, 60 (Amy Gutmann ed., 1997). 
be limited to circumstances in which it would be exercised for the benefit of the entire public.

\section{The Post-Revolutionary Influence of Republicanism}

Republicanism is commonly described as the ideology of the American Revolution. ${ }^{114}$ Yet, for it to have any relevance to the original understanding of the Fifth Amendment's "public use" requirement, its influence must have persisted into the early national period. The first students of republican ideology believed that it exerted only mild influence after the American Revolution, when it was eclipsed by liberalism as the new nation's dominant political theory. Writing during the first years of republican historiography, Professor Wood argued that republicanism as an autonomous body of thought had collapsed by 1787, and that the Constitution represented its repudiation. ${ }^{115}$ More recently, William Michael Treanor has sharply contrasted the influences of the ascendant liberalism, which he associated with federalism, and republicanism, which he associated with anti-federalism. ${ }^{116}$

114. See supra notes 50-53 and accompanying text.

115. See WoOD, CreAtion, supra note 15, at 499-500; see also Katz, supra note 20, at 48486 (touting the years 1776-1787 as the "brief moment of triumph" for republican theory); Treanor, Note, supra note 15, at 715-16 (arguing that, with the adoption of the Constitution, "the future belonged to liberalism"). Scholars also believed, correspondingly, that liberalism played almost no role in American politics prior to the adoption of the Constitution. See PoCOCK, supra note 15, at 507; Sellers, supra note 54, at 4 (asserting that “'[1]iberalism' as such was not known before the nineteenth century").

116. See, e.g., Treanor, Note, supra note 15, at 713; see also BAILYN, supra note 10 , at 331 ("[I]n the context of the great mass of ratification documents, the anti-federalists emerge as the ones who kept the faith."); Cecelia M. Kenyon, Men of Little Faith: The Anti-Federalists on the Nature of Representative Government, 12 WM. \& MARY Q. 3, 38-43 (1955) (suggesting that anti-Federalists generally remained faithful to republican theory).

Besides too neatly describing the respective influences of republicanism and liberalism, this dichotomy inadequately describes the intellectual universe of anti-federalism. If the antiFederalists were influenced only by republican theory, why did they demand the addition of a bill of rights to the Constitution? Republicans, who trusted popularly elected legislatures to protect the people's interests, see supra notes 68-73 and accompanying text, would have viewed a bill of rights as unnecessary. Put another way, why would the anti-Federalists have attempted to restrain the national legislature if they adhered to the republican belief that legislatures generally pursue the public's interest?

One explanation is that, like their rivals, the anti-Federalists may have been influenced by liberalism's respect for individual rights and distrust of legislatures. Second, they may have retained the republican belief that distant legislators were more likely to become corrupted and to develop interests in opposition to the people's. See MCDONALD, supra note 60, at 285 (identifying the anti-federalist notion that "[o]nly a small republic could maintain the voluntary attachment of the people and a voluntary obedience to its laws, make government responsible to 
Scholars now generally agree that republicanism continued to influence American politics well into the first decades of the nineteenth century. ${ }^{117}$ Professor Alexander has stressed the "interdependency" of republican and liberal ideas, noting that eighteenth-century political dialogue contained conflicting and contradictory strands of both. ${ }^{118}$ Both Professors Wood and Treanor have recanted their earlier views, now concluding that republicanism remained influential through the War of $1812 .{ }^{119}$ Professor Wood emphasizes contemporaries' predictions that the late conflict with England would cause a revitalization of public-mindedness and devotion to the common good, ${ }^{120}$ and even as late as 1816, President Monroe gave voice to the traditional republican idea that political parties were unnecessary to a free government. ${ }^{121}$ For his part, Professor Treanor argues that the Takings Clause embodies both republicanism and liberalism, as it recognizes the republican principle that government ought not diminish the value of private property and accepts the liberal notion that certain fundamental rights must be above majoritarian determination. ${ }^{122}$

To be sure, republicanism was not without its post-independence critics. The Federalist No. 10, authored by James Madison and published in late 1787, directly challenged the republican notion that the public shares the same interests. Madison criticized republicans for

the people, and inculcate the people with republican virtue"); WOOD, CREATION, supra note 15 , at 356 (asserting that "few in 1776 conceived of the thirteen states becoming a single republic, one community with one pervasive public interest"). Finally, anti-Federalists may not actually have desired a bill of rights, but simply used its absence as an argument against the Constitution's ratification. See ForREST MCDONALD, E PluRIBUS UnUM: THE FORMATION OF THE AMERICAN REPUBLIC, 1776-1790, at 317 (2d ed. 1979) (speculating that the absence of a bill of rights "provided an excellent popular ground on which certain other opponents of the Constitution, themselves motivated by personal interest, could attack the document"); WoOD, CREATION, supra note 15, at 537 (remarking that "the Federalists believed that the frenzied advocacy of a bill of rights by most Antifederalists masked a basic desire to dilute the power of the national government in favor of the states").

117. See Treanor, Political Process, supra note 15, at 823 (identifying the "near consensus" that both republicanism and liberalism were influential during the last decades of the eighteenth century). Scholars have also, correspondingly, identified elements of liberal theory in political discourse well before the Revolution. Professor Mensch, for instance, has identified certain tensions in property-rights theory as early as 1720 that would eventually culminate in outright liberalism. See Elizabeth V. Mensch, The Colonial Origins of Liberal Property Rights, 31 BUFF. L. REV. 635, 678-90 (1982).

118. Alexander, supra note 50, at 275-76.

119. See Wood, Radicalism, supra note 74, at 327; Treanor, Political Process, supra note 15 , at 823,826 n.226.

120. See Wood, RAdicalism, supra note 74, at 327.

121. See id. at 298.

122. See Treanor, Political Process, supra note 15, at 819. 
"erroneously suppos[ing] that by reducing mankind to a perfect equality in their political rights, they would at the same time be perfectly equalized and assimilated in their possessions, their opinions, and their passions." ${ }^{123}$ Instead, the natural state of a republican government is to be rife with opposing factions: "Liberty is to faction what air is to fire ...." ${ }^{\prime 24}$ Some years earlier in a letter to Thomas Jefferson, Madison had identified economic interests as the basis of these factions: "Give all power to property, and the indigent will be oppressed. Give it to the latter and the effect may be transposed."

This dawning recognition that different economic classes had different interests eventually led to the rejection of republicanism's core assumption. ${ }^{126}$ However, at the time of its publication, The Federalist No. 10 exerted only limited influence on American political theory. Few of Madison's contemporaries were swayed by his "extended republic" theory, which predicted the stability of large-scale republics based on their ability to balance conflicting factions. ${ }^{127}$ More strikingly, few readers were even able to comprehend The Federalist No. 10 's central point. ${ }^{128}$ Hence the early national period did witness the ascendancy of Federalist liberalism, but American politics continued to be powerfully influenced by the residue of republican theory.

123. The Federalist No. 10, at 81 (James Madison) (Clinton Rossiter ed., 1961).

124. Id. at 78 .

125. Madison's Observations on Jefferson's Draft of a Constitution for Virginia, in 6 JEFFERSON PAPERS, supra note 85, at 308, 310 (1952).

126. See Treanor, Note, supra note 15, at 704-05 (arguing that the redistributive acts of various Revolutionary state legislatures exposed the ignored fissures between certain social groups and, in turn, undermined the republican assumption of uniform interests).

127. See Larry D. Kramer, Madison's Audience, 112 HARV. L. REV. 611, 667 (1999) ("Yet in all the torrent of pamphlets and essays and articles that streamed from the presses-enough to fill many volumes - there are only the Federalist Papers and these two other essayists to suggest that Madison's theory of the extended republic was part of the debate at all."); see also DOUGLASS ADAIR, The Tenth Federalist Revisited, in FAME AND THE FOUNDING FATHERS: ESSAYS BY DOUGLASS ADAIR 75, 75-76 (Trevor Colbourn ed., 1974) ("[Prior to 1913,] practically no commentator on The Federalist or the Constitution, [and] none of the biographers of Madison, had emphasized Federalist 10 as of special importance for understanding our 'more perfect union."”).

128. See Kramer, supra note 127, at 670 ("Only a small handful of Federalists understood Madison's reasoning well enough to assert it at all, and they could offer it to an audience that was, if anything, less likely to be comprehending or receptive than was the audience in Philadelphia."). 


\section{HistoricAl PRACTICES AND EMINENT DOMAIN}

Historical clues to the original understanding of the Fifth Amendment's "public use" requirement are somewhat limited. Federal statutes from this period are unavailable, as the national government did not make use of its eminent domain power until the late nineteenth century, ${ }^{129}$ and federal judicial interpretations are similarly lacking owing to the Supreme Court's early ruling that the Fifth Amendment did not bind the states. ${ }^{130}$ Nor is there an elaborate record of state appellate opinions from the colonial and Revolutionary periods. ${ }^{131}$ However, early state and colonial statute books reveal two uses of eminent domain relevant to the meaning of public use: the Mill Acts, which effectively allowed private landowners to condemn the land of neighboring riparians, and private road acts, whereby states authorized the construction of thoroughfares for the sole benefit of particular persons. These statutes are crucial evidence that the founding generation accepted the public-benefit theory, as they were enacted in the face of state constitutional imperatives-models for the Fifth Amendment's Takings Clause-that private property be taken only for a public use.

\section{A. State Constitutions}

Although something resembling the Takings Clause may be traced as far back as Magna Carta ${ }^{132}$ the notion that eminent domain should be exercised only for public purposes was introduced to America by a 1641 statute. That law, part of the Massachusetts Body of Liberties, apparently authorized only the seizure of personal property, providing that "[n]o mans Cattel or goods of what kinde soever

129. See Eric Grant, A Revolutionary View of the Seventh Amendment and the Just Compensation Clause, 91 Nw. U. L. REv. 144, 173 \& n.122 (1996).

130. See Barron v. Mayor and City Council of Baltimore, 32 U.S. (7 Pet.) 243, 250-51 (1833).

131. See FRIEDMAN, supra note 113, at 33 .

132. Chapter 28 of Magna Carta prohibited the Crown from taking "corn or other provisions ... without immediately tendering money therefor," Magna Carta ch. 28 (1215), reprinted in MCKECHNIE, supra note 106, at 329, and chapter 39 provided that "[n]o freeman shall be ... disseised ... except by the lawful judgment of his peers or [and] by the law of the land," id. ch. 39, reprinted in MCKECHNIE, supra note 106, at 375 . The first provision substantively guaranteed compensation ("tendering money therefor"), whereas the second only imposed a requirement of procedural regularity ("by the law of the land"). By specifying that a landowner could be dispossessed "by the lawful judgment of his peers," chapter 39, like several of the later state constitutions, regarded legislators' consent as a proxy for that of the subject. See infra notes 143-46 and accompanying text. 
shall be pressed or taken for any publique use or service, unlesse it be by warrant grounded upon some act of the generall Court ...."133 A similar restriction, but one allowing condemnation of land, appeared in the Fundamental Constitution of Carolina, which was authored by John Locke in 1669 but never went into effect: "The damage the owner of such lands (on or through which any such public things shall be made) shall receive thereby, shall be valued, and satisfaction made, by such ways as the grand council shall appoint." ${ }^{134}$ Because "such public things" referred to highways and buildings, ${ }^{135}$ the Fundamental Constitution embodied a stringent "public use" requirement. The state was not permitted to take private property for the purpose of rendering a benefit to the public; instead, property could be taken only to construct a "public thing."

In 1776, Pennsylvania and Virginia became the first states to include the familiar "public use" language in their constitutions, ${ }^{136}$ and, in all, six of the first thirteen states' constitutions contained "public use" limitations of nearly identical phraseology. ${ }^{137}$ Several states'

133. A Coppie of the Liberties of the Massachusetts Collonie in New England $\S 8$ (1641), reprinted in 5 SOURCES AND DOCUMENTS OF UNITED STATES CONSTITUTIONS 46, 48 (William F. Swindler ed., 1975) (emphasis added).

134. FundAMENTAL CONSTITUTION OF CAROLINA art. 44 (1669), reprinted in 2 CUSHING'S NORTH CAROLINA LAWS, supra note 96, at 137, 142 (emphasis added).

135. See id. (granting the High Steward's Court authority to "make any public building, or any new highway, or enlarge any old highway upon any man's land whatsoever; as also to make cuts channels, banks, locks and bridges for making rivers navigable, or for draining fens, or any other public use").

136. See Stoebuck, supra note 4 , at 591 .

137. Delaware, Massachusetts, New Hampshire, Pennsylvania, Vermont, and Virginia included some sort of "public use" restriction in their early constitutions.

Delaware: "[N]or shall any man's property be taken or applied to public use without the consent of his representatives, and without compensation being made." DEL. CONST. of 1792, art. I, $\S 8$, reprinted in 1 THORPE, supra note 3, at 569 (emphasis added).

Massachusetts:

$[\mathrm{N}] \mathrm{o}$ part of the property of any individual can, with justice, be taken from him, or applied to public uses, without his own consent, or that of the representative body of the people.... Whenever... the property of any individual should be appropriated to public uses, he shall receive a reasonable compensation therefor.

MASS. CONST. of 1780, pt. 1, art. X, reprinted in 3 THORPE, supra note 3, at 1891 (emphases added).

New Hampshire: "But no part of a man's property shall be taken from him, or applied to public uses, without his own consent, or that of the representative body of the people." N.H. CONST. of 1784, pt. I, art. XII, reprinted in 4 THORPE, supra note 3, at 2455 (emphasis added).

Pennsylvania: "But no part of a man's property can be justly taken from him, or applied to public uses, without his own consent, or that of his legal representatives ...." PA. CONST. of 1776, Declaration of Rights, art. VIII, reprinted in 5 THORPE, supra note 3, at 3083 (emphasis added). 
takings clauses contained auxiliary language implying that the government should not take private property simply to produce public benefits. In addition to restricting the power of eminent domain to takings for a public use, these states further limited the government's power to expropriate private property by requiring that a taking be justified by "public necessity" or "the public exigencies." 138 Vermont specified that "private property ought to be subservient to public uses, when necessity requires it," ${ }^{139}$ and the Massachusetts constitution expressed the same idea: "And whenever the public exigencies require that the property of any individual should be appropriated to public uses, he shall receive a reasonable compensation therefor." ${ }^{140}$ Similar limiting language appeared in the Northwest Ordinance. ${ }^{141}$ Although the constitution-makers did not specify what was meant by "necessity," the additional limitation of eminent domain to situations where the "public exigencies" made it essential implies a narrow conception of what qualified as a public use.

Other constitutions contained language heralding looser restrictions on eminent domain. In Virginia's takings clause, for instance, the powers of taxation and eminent domain were linked: "that all men ... cannot be taxed or deprived of their property for public uses without their consent ...." ${ }^{142}$ By associating the power to take prop-

Vermont: "That private property ought to be subservient to public uses, when necessity requires it; nevertheless, whenever any particular man's property is taken for the use of the public, the owner ought to receive an equivalent in money." VT. CONST. of 1786, ch. I, art. II, reprinted in 6 THORPE, supra note 3, at 3752 (emphasis added). Identical language appeared in Vermont's 1777 constitution, which was submitted to the people but never ratified. See VT. CONST. of 1777, ch. I, art. II, reprinted in 6 THORPE, supra note 3 , at 3740.

Virginia: "[T] $]$ hat all men, having sufficient evidence of permanent common interest with, and attachment to, the community, have the right of suffrage, and cannot be taxed or deprived of their property for public uses, without their own consent, or that of their representatives so elected ...." VA. CONST. of 1776, Bill of Rights, $\$ 6$, reprinted in 7 THORPE, supra note 3, at 3813 (emphasis added).

138. See Stoebuck, supra note 4, at 592 (arguing that the inclusion of the "necessity" elements reflected lawmakers' "imperfectly defined desire to limit the taking power").

139. VT. CONST. of 1786, ch. I, art. II, reprinted in 6 THORPE, supra note 3, at 3752 (emphasis added).

140. MASs. CONST. of 1780, pt. 1, art. X, reprinted in 3 THORPE, supra note 3, at 1891 (emphasis added).

141. See Ordinance for the Government of the Territory of the United States North-west of the River Ohio, art. 2 (July 13, 1787), reprinted in 1 DOCUMENTARY HISTORY, supra note 77, at 168, 172 ("[S]hould the public exigencies make it Necessary for the common preservation to take any persons property, or to demand his particular services, full compensation shall be made for the same ...." (emphases added)).

142. VA. CONST. of 1776, Bill of Rights, $\S 6$, reprinted in 7 THORPE, supra note 3 , at 3813 
erty with the power to tax, Virginia implied that a duly represented citizen's property rights were no more threatened by outright condemnation than by taxation. States further weakened-indeed, gutted-their takings clauses by specifying that the legislative decision to seize property was equivalent to the landowner's consent. ${ }^{143}$ Pennsylvania's takings clause provided that "no part of a man's property can be justly taken from him, or applied to public uses, without his consent, or that of his legal representatives, ${ }^{144}$ and Virginia similarly required the consent of landowners "or that of their representatives so elected ...."145 These provisions reflect republicanism's assumption of the uniformity of interests between citizen and lawmaker. ${ }^{146}$ A legislator was deemed competent to sacrifice citizens' interests, presumably because he himself shared those interests.

\section{B. The Mill Acts}

Perhaps the most common uses of the eminent domain power during the colonial and Revolutionary periods were the Mill Acts, ${ }^{147}$ the first of which was enacted by Virginia in $1667 .{ }^{148}$ Eventually adopted by ten colonies/states, ${ }^{149}$ the Mill Acts authorized riparian

143. See Stoebuck, supra note 4, at 569 ("If one accepts the principle of representative government, there is no compulsory taking, but rather a voluntary relinquishment by delegated consent.").

144. PA. CONST. of 1776, Declaration of Rights, art. VIII, reprinted in 5 THORPE, supra note 3 , at 3083 (emphasis added).

145. VA. CONST. of 1776, Bill of Rights, $\S 6$, reprinted in 7 THORPE, supra note 3, at 3813; see also MASs. CONST. of 1780, pt. 1, art. X, reprinted in 3 THORPE, supra note 3, at 1891 ("[N]o part of the property of any individual can, with justice, be taken from him, or applied to public uses, without his own consent, or that of the representative body of the people." (emphasis added)); N.H. CONST. of 1784, pt. I, art. XII, reprinted in 4 THORPE, supra note 3, at 2455 ("But no part of a man's property shall be taken from him, or applied to public uses, without his own consent, or that of the representative body of the people." (emphasis added)).

146. See supra notes 68-73 and accompanying text.

147. See Berger, supra note 12, at 205 (identifying the construction of mill dams and roads as the two projects most often requiring the use of eminent domain).

148. See Melton, supra note 11 , at 73 \& n.91. But see MORTON J. Horwitz, ThE TRANSFORMATION OF AMERICAN LAW, 1780-1860, at 47 (1977) (claiming, erroneously, that Massachusetts enacted the first Mill Act in 1713).

149. Connecticut, Delaware, Maryland, Massachusetts, New Hampshire, North Carolina, Pennsylvania, Rhode Island, South Carolina, and Virginia operated Mill Acts during the colonial, Revolutionary, and early national eras. A comprehensive list of Mill Acts in effect between 1667 and 1885 may be found in Head v. Amoskeag Manufacturing Co., 113 U.S. 9, 17 n.* (1885).

Connecticut: An Act for preventing, and removing Nuisances in High-Ways, Rivers, and Water Courses (date of passage unknown) [hereinafter Connecticut Mill Act], in ACTS AND LAWS OF THE STATE OF CONNECTICUT, IN AMERICA 327 (1796) [hereinafter CONNECTICUT 
landowners to construct dams to build up heads of water that were necessary for the operation of mills. The Acts limited the compensation that mill owners were required to pay for the damage they caused when neighboring landowners' holdings became flooded. Moreover, the Acts prevented aggrieved riparians from pursuing the common law remedies of injunctive relief or self-help. ${ }^{150}$ In essence,

LAWS].

Delaware: An ACT to encourage the Building of good Mills in this Government (date of passage unknown) [hereinafter Delaware Mill Act], reprinted in THE EARLIEST PRINTED LAwS OF Delaware 1704-1741, at 42 (John D. Cushing ed., 1978) [hereinafter Cushing's DELAWARE LAWS].

Maryland: An Act for the Encouragement of an Iron Manufacture, within this province (June 8, 1719) [hereinafter Maryland Mill Act of 1719], in 33 ARCHIVES OF MARYLAND 467 (1913); An Act for encouragement of such persons as will undertake to build Water-Mills (June 2, 1692) [hereinafter Maryland Mill Act of 1692], in 13 ARCHIVES OF MARYLAND 534 (1894).

Massachusetts: An Act in Addition to the Act for Upholding and Regulating of Mills (Feb. 22, 1714) [hereinafter Massachusetts Mill Act], in 1 THE ACTS AND RESOlves, PUBLIC and Private, of the Province of the Massachusetts Bay 729 (1869) [hereinafter MASSACHUSETTS LAWS].

New Hampshire: An Act for the Regulating of Mills (May 13, 1718) [hereinafter New Hampshire Mill Act], reprinted in ACTS AND LAWS OF NEW HAMPSHIRE, 1680-1726, at 92 (John D. Cushing ed., 1978) [hereinafter Cushing's NEW HAMPSHIRE LAws].

North Carolina: An Act, to encourage the Building of Mills (Jan. 19, 1715) [hereinafter North Carolina Mill Act], reprinted in 1 CUSHING'S NORTH CAROLINA LAWs, supra note 96, at 18.

Pennsylvania: An ACT to authorise any person or persons owning lands adjoining navigable streams of water, declared public highways, to erect dams upon such streams, for mills and other water works (Mar. 23, 1803) [hereinafter Pennsylvania Mill Act], reprinted in JoHN W. Purdon, A Digest of the Laws OF Pennsylvania, 1700-1830, at 645 (1831) [hereinafter PENNSYlVania Laws].

Rhode Island: An act for regulating Water-Mills (1734) [hereinafter Rhode Island Mill Act], in The Public Laws of the State of Rhode-Island and Providence PlANTATIONS 374 (1822) [hereinafter RHODE IsLAND LAws].

South Carolina: An Act for ... encouraging the... building [of] Sawmills and other Mechanick Engines (June 7, 1712) [hereinafter South Carolina Mill Act], reprinted in 1 THE EARliest PRINTEd Laws OF SOUTH CAROLINA, 1692-1734, at 285 (John D. Cushing ed., 1978) [hereinafter CuSHING's SOUTH CAROLINA LAws].

Virginia: An act for encouragement for erecting Mills (Sept. 23, 1667) [hereinafter Virginia Mill Act], in 2 The Statutes at Large; Being a Collection of all the Laws of VIRGINIA 260 (William Waller Hening ed., 1823) [hereinafter VIRGINIA LAWs].

150. See Massachusetts Mill Act $\S 3$, in MASSACHUSETTS LAWs, supra note 149, at 730 ("And the jurors' verdict... shall be a sufficient bar against any action to be brought for any damages occasioned by the flowing of any such lands as aforesaid ...."); New Hampshire Mill Act, reprinted in CUSHING'S NEW HAMPSHIRE LAwS, supra note 149, at 93 ("[T] he Jurors Verdict ... shall be a sufficient Bar against any Action to be brought for any damages occasioned by the flowing of any such Lands or Marsh, as aforesaid ...."); Rhode Island Mill Act § 1, in RHODE ISLAND LAWS, supra note 149, at 375 ("[T] he juror's verdict . . . shall be a sufficient bar against any action to be brought for any damages occasioned by the flowing of such lands as aforesaid ...."). 
the Mill Acts delegated the power of eminent domain to private landowners, and permitted them effectively to condemn for their own uses land that, as Delaware's assembly archly put it, "may happen to be another Man's Property."

Although the essential features of the Mill Acts were fairly uniform among the states, ${ }^{152}$ several important variations existed. One Act authorized the construction of only those mills that did not impair neighboring landowners' enjoyment of their property. ${ }^{153}$ Some Acts limited mill operators' liability to upstream riparians or those on the opposite bank, ${ }^{154}$ while others permitted the flooding of downstream land. ${ }^{155}$ A more significant difference concerned ownership of the flooded land. Most Acts only specified the damages due to neighboring landowners, ${ }^{156}$ but several actually transferred the land's title to the owner of the mill. ${ }^{157}$

151. Delaware Mill Act, reprinted in CUSHING's DELAWARE LAWS, supra note 149, at 43; see also Berger, supra note 12, at 206 ("In effect, then, the lower riparian had a right to condemn the lands of his upper neighbor by flooding.").

152. The surprising uniformity among early American laws is attributable to the fact that many colonies consulted their neighbors' statute books before drafting their own. See FRIEDMAN, supra note 113, at 92 ("[N]ewer settlements found it convenient to borrow laws from older neighbors, who had similar outlooks, goals, experiences, and problems."). Particularly influential were the laws of Massachusetts: when drafting its 1656 code, New Haven's assembly directed the colonial governor to "'send for one of the new booke of laws in the Massachusetts colony," George L. Haskins \& Samuel E. Ewing, III, The Spread of Massachusetts Law in the Seventeenth Century, 106 U. PA. L. REV. 413, 416 (1958) (footnote omitted), and 64 of the 78 provisions appearing in Connecticut's 1650 code derived from Massachusetts law. See id. at 414-15; see also FRIEDMAN, supra note 113, at 92-93; Stefan Riesenfeld, Law-Making and Legislative Precedent in American Legal History, 33 MINN. L. REV. 103, 132 (1949) (discussing the widespread emulation of Massachusetts's 1648 Laws and Liberties).

153. See Pennsylvania Mill Act $\S 1$, in Pennsylvania Laws, supra note 149, at 645 ("[T]he person or persons so erecting said dam or dams shall not infringe on or injure the rights and privileges of the owner or possessor of any private property on such stream.").

154. Delaware's Mill Act allowed a mill operator to flood the land "on either Side of the said Creeks, Rivers, or Runs," Delaware Mill Act, reprinted in CUSHING's DELAWARE LAwS, supra note 149, at 43, and Virginia's Mill Act permitted millers owning "land only on one side of the said place" to condemn land on the river's other bank, Virginia Mill Act, in 2 VIRGINIA LAWs, supra note 149 , at 260.

155. In 1825, Massachusetts amended its Mill Act to authorize flooding of any land "situated either above or below any mill dam." An Act in addition to an Act, entitled "An Act for the support and regulation of Mills," and the several Acts in addition thereto (Feb. 26, 1825), in 3 The General Laws of MassachusetTs, 1822-1831, at 102 (Theron Metcalf ed., 1832). Professor Horwitz speculates that this change was made to accommodate large cotton mills, which required considerable amounts of water to be released downstream. See HoRWITZ, supra note 148 , at 50 .

156. New Hampshire empowered juries to award damages upon a "faithful indifferent Apprizal of the damage done to the Person complainant ...." New Hampshire Mill Act, reprinted in CUSHING'S NEW HAMPSHIRE LAWS, supra note 149, at 93. Massachusetts similarly provided 
A number of legislatures justified the Mill Acts' burden on other landowners by expressly contemplating, in true republican fashion, that the mills would produce a public good. ${ }^{158}$ Some evidence, however, indicates that the Mill Acts were not universally believed to produce unmitigated benefits, as certain states exhibited a particular concern for the effect of mills on other citizens. ${ }^{159}$ South Carolina went so far as to repeal its Mill Act on the grounds that it too greatly interfered with private landowners' interests. Its legislature found that "it hath (of late) been frequently the practice of many persons to make dams or banks" that resulted in "manifest prejudice" to their neighbors. In order to "prevent ... the like evil for the future," it therefore required justices of the peace to "immediately make an order to cut open the said bank or dam in such a manner as to prevent

that juries should award damages upon making "a faithful, indifferent apprisal of the yearly damage done to [the] [any] person complainant, by flowing his or their land as aforesaid." Massachusetts Mill Act $\S 2$, in MASSACHUSETTS LAWS, supra note 149, at 729 (alterations in original). Rhode Island juries were directed to make "a faithful and impartial appraisal of the yearly damage done to the lands of the person complaining as aforesaid ...." Rhode Island Mill Act $\S$ 1, in RHODE IsLAND LAWS, supra note 149, at 375.

157. The Delaware Mill Act authorized local justices of the peace to "transfer forever a good Title in Fee" to the flooded land, upon determining its "true and intrinsick Value." Delaware Mill Act, reprinted in CUSHING's DELAWARE LAWS, supra note 149, at 43-44. Maryland permitted operators of iron mills to be "invested with an absolute Estate of Inheritance in One Hundred Acres of such Land," Maryland Mill Act of 1719, art. II, in 33 ARCHIVES OF MARYLAND, supra note 149, at 467, even though it allowed grist and saw mill owners to obtain only an 80-year lease to 20 acres of adjoining land, see Maryland Mill Act of 1692, in 13 ARCHIVES OF MARYLAND, supra note 149, at 536.

158. The Delaware Mill Act speculated that "the Country [might] lose the Benefit of the said Mill" if mill owners were not immunized from suits by neighboring landowners. Delaware Mill Act, reprinted in Cushing's Delaware LAws, supra note 149, at 43. Maryland recognized that establishing a forging mill would undoubtedly "be considerably advantageous to the Persons immediately concerned therewith," but conjectured that such a mill would also result in "the Increase of our Trade and Navigation [and] the Peopling of this Province ...." Maryland Mill Act of 1719, in 33 ARCHIVES OF MARYLAND, supra note 149, at 467. Likewise South Carolina: "IN this Province the Number of Inhabitants being few for so great Extent of Land, the erecting of Mills of all kinds and other Mechanick Engines, will greatly improve the Country it self and its Trade and Navigation...." South Carolina Mill Act, art. XII, reprinted in CUSHING'S SOUTH CAROLINA LAWS, supra note 149, at 288.

159. States' sensitivity to the interests of other property owners is material to an issue presently being explored in the academic literature. In a recent article, Professor Hart has contended that early American lawmakers routinely compromised private property rights through regulatory regimes designed to secure various public benefits. See John F. Hart, Colonial Land Use Law and Its Significance for Modern Takings Doctrine, 109 HARV. L. REV. 1252 (1996). Hart's argument is based, in part, on the Mill Acts. See id. at 1266-67. His claim is weakened insofar as certain states reconsidered their encouragement of mill construction in order to protect other citizens' use of their property. 
any further damage...."160 Other colonial assemblies voiced like concerns. ${ }^{161}$

Many of the authorized mills were public utilities, not purely private enterprises, as they were required by law to grind the grain of all citizens. ${ }^{162}$ In particular, North Carolina designated such mills as "Public Mills," and required their owners to "grind Wheat and Indian Corn for all such Persons as shall require the same ...."163 Rhode Island similarly recognized the duty of "all Millers, and Persons tending Mills" to "make good Meal, according to custom, and grind for each Person bringing Corn or Grain to be ground, in their turn, without Distinction ...." 164 Additionally, millers were subject to strict regulations that governed the rates they could charge for grinding grain. Rhode Island mill owners were enjoined from taking more than one-sixteenth of the grain they ground, ${ }^{165}$ and Virginia more generously forbade millers from "tak[ing] above the sixth part thereof for toll." ${ }^{166}$ Thus, the Mill Acts that authorized public mills

160. An Act for regulating the making of Dams or banks for reserving water, where the same may affect the propertys of other persons (May 29, 1744), in 3 THE STATUTES AT LARGE of SOUTH CAROLINA 609 (Thomas Cooper ed., 1838) [hereinafter South CAROLINA LAws].

161. Rhode Island's Act required mill owners to maintain a waste-water gate "sufficient to vent so much water as naturally runs in said river" if it was "desired by any persons owning any mill within one mile below such mill on the same stream ...." Rhode Island Mill Act $\S 4$, in RHODE ISLAND LAWS, supra note 149, at 376-77. Connecticut's legislature prohibited the damming of rivers and brooks on the grounds that it was often prejudicial to towns and landowners, although it extended special treatment to mill dams: "[T]his Act, or any thing herein contained, shall not be understood or intended to hinder any dam for any Mill . ..." Connecticut Mill Act, in CONNECTICUT LAWs, supra note 149, at 327-28.

162. See FRIEDMAN, supra note 113, at 76 (describing the various duties imposed on mill operators by colonial governments); 1 JOHN LEWIS, A TREATISE ON THE LAW OF EMINENT DOMAIN IN THE UNITED STATES § 275, at 545 (3d ed. 1909) ("Most of the mills which existed in these early years were grist mills and saw-mills .... [that] were regulated by law and compelled to serve the public for a stipulated toll and in regular order."); Berger, supra note 12, at 206 ("In the earliest days the mills were grist mills generally required to be open to the public for the grinding of corn."). One exception to the rule is Maryland's 1719 Mill Act. Instead of authorizing the construction of grain mills that would be held open to the public, it permitted riparian landowners to build privately operated iron mills. See Maryland Mill Act of 1719, in 33 ARCHIVES OF MARYLAND, supra note 149, at 467.

163. North Carolina Mill Act art. V, reprinted in Cushing's NORTH CAROLINA LAws, supra note 96 , at $18-19$.

164. An Act for the Regulating of Millers in their taking of Tole (May 3, 1726), in ACTS AND LAWS OF THE COLONY OF RHODE-IsLAND 141, 142 (1730) [hereinafter ACTS OF RHODE ISLAND].

165. See id. at 141 .

166. Act of November 20, 1645, act IV, reprinted in 2 COLONY LAWS OF VIRGINIA 16191660, at 301 (John D. Cushing ed., 1978). Connecticut allowed a miller "three Quarts out of each Bushel of Indian Corn he grinds, and of other Grain two Quarts out of each Bushel he 
more resemble the chartering of a utility to perform a public function than the condemnation of land for another citizen's benefit. ${ }^{167}$

Scholars generally regard the Mill Acts as evidence that the founding generation approved the constitutionality of takings that did not vest the entire public with rights of use, but only produced an indirect benefit to the public. One commentator has concluded that, given the Mill Acts' coexistence with "public use" requirements in state constitutions, "it is doubtful that the draftsmen [of the Fifth Amendment] thought condemnation could be only for the literal use of the public." ${ }^{\prime 168}$ At least one early court appears to have shared this recognition. In Skipwith v. Young, ${ }^{169}$ the Virginia Supreme Court upheld that state's Mill Act because "the property of another is, as it were, seized on, or subjected to injury, to a certain extent, it being considered in fact for the public use." ${ }^{, 70}$ The public use identified by the court was the benefit to the community of having the mill. ${ }^{171}$

The conventional account appears generally correct, but it wants two important qualifications. First, since many seventeenth-century mills were public utilities open by law equally to all members of the public, the Acts authorizing them satisfied the actual-use, not the

grinds; except Malt, out of each Bushel of which he grinds he shall be allowed one Quart, and no more." An Act concerning Mills and Millers (date of passage unknown), in CONNECTICUT LAWS, supra note 149, at 314-15. New Hampshire provided millers with scales and weighs to assist them in measuring grain, and stipulated that they were entitled to take "one Sixteenth part, and no more" (except "Indian Corn, for which the Mill shall take one Twelfth"). New Hampshire Mill Act, reprinted in CUSHING's NEW HAMPSHIRE LAWS, supra note 149, at 92. Similar laws appeared in North Carolina and Vermont. See North Carolina Mill Act art. V, reprinted in CUSHING'S NORTH CAROLINA LAws, supra note 96, at 19; An Act Regulating Mills and Millers (Feb. 17, 1779), in 12 LAws OF VERMONT, 1777-1780, at 77 (Allen Soule ed., 1964) [hereinafter VERMONT LAWS].

167. See MCDONALD, supra note 60, at 35 (recognizing that assemblies had long regulated privately owned mills, dams, bridges, and ferries as public utilities).

168. Stoebuck, supra note 4, at 595; see also Berger, supra note 12, at 206-07 (arguing that the Mill Acts signal "the early acceptance of the broad view that it was the great advantage to the public which justified the taking, even though a private individual undoubtedly received a substantial and perhaps greater benefit, and even though the public had no right to use the property"); Melton, supra note 11, at 75 (arguing that "the mill acts' drafters had a broad concept of public use"); Comment, supra note 9, at 605 ("No clearer instance of a taking of property for the benefit of private individuals could be presented, and literal application of the "use by the public' test would seemingly require invalidation."); cf. Hart, supra note 159, at 1267 ("The land and the intended use [of the authorized mills] were private; the benefit to the public accrued only indirectly.").

169. 19 Va. (5 Munf.) 276 (1816).

170. Id. at 278 .

171. See id. 
public-benefit, test. ${ }^{172}$ These mills therefore cannot be cited as evidence that public benefit was widely accepted as the takings benchmark. Second, many modern commentators rely on the privately held and operated mills of the nineteenth century to prove the founding generation's acceptance of public-benefit takings. ${ }^{173}$ Laws authorizing such mills are indeed examples of public-benefit takings, since nineteenth-century mills increasingly became industrial enterprises used exclusively by their owners and not typically subject to public-access regulations. ${ }^{174}$ But nineteenth-century mills, of course, are of little value in explaining the founding generation's views.

\section{Construction of Private Roads}

Besides the more common public roads, which were open for the use of all citizens and maintained by states or localities, early American governments occasionally permitted the seizure of land for the construction of so-called private roads. Private roads appeared in a number of incarnations, but each involved the state deploying the power of eminent domain, or effectively permitting private parties to do the same, to build roads that are now recognized as having benefited a discrete group (either individual landowners or inhabitants of a particular locale) ${ }^{175}$ The New York Supreme Court of Judicature's description of private roads was not atypical:

The road is paid for and owned by the applicant. The public has no title to it, nor interest in it. No citizen has a right to use the road as he does the public highway. He can only use it when he has business with the road owner, or some other lawful occasion for going to the

172. See Head v. Amoskeag Mfg. Co., 113 U.S. 9, 18-19 (1885) ("The principle [sic] objects, no doubt, of the earlier acts were grist-mills; and it has generally been admitted . . . that a gristmill which grinds for all comers, at tolls fixed by law, is for a public use.").

173. See, e.g., Nichols, supra note 12, at 619 (admitting that many early mills were in the form of public utilities, but arguing that in later years the Acts benefited industries with no such duties to the public).

174. Professor Horwitz believes that Mill Act mills took on an increasingly private character around the turn of the nineteenth century. See HoRwITZ, supra note 148, at 49. One early commentator objected to interpreting the Mill Acts to permit the construction of industrial mills precisely because of this contrast. The newfangled textile mills, he instructed, authorized private persons "to apply the property of any one against his consent to private uses." Joseph K. Angell, The Law of Water Privileges, 2 AM. JuRIST 25, 34 (1829). In the colonial era, by contrast, the corn and saw mills were open to the public and, therefore, "public easements." Id. at 30-31.

175. See 2A Nichols on Eminent Domain, supra note 22, § 7.06[4][a]-[b], at 7-119 to 7124; Berger, supra note 12, at 207. 
land intended to be benefited by the road.... Even the owner of the land over which the road passes ... has no right to use the road for his own purposes.... In short, the road is the private property of the applicant. ${ }^{176}$

Most commonly, private roads were constructed by the states themselves. Colonial Massachusetts authorized each town's selectmen "to lay out or cause to be laid out, particular and private wayes, for such town only, as shall be thought necessary," but specified that "no damage [shall] be done to any particular person in his land or propriety without due recompence [sic] to be made by the town ...."177 Twenty years later, the colony expanded its private road regime. Because "the lands of particular persons or proprietors may be and are so scituated [sic] and circumstanced as to make or render a particular or private way, for the use of such person or proprietor, of absolute necessity," Massachusetts directed its selectmen to:

lay out, or cause to be laid out, particular or private ways, between any of the inhabitants or proprietors within their respective towns, as shall be thought necessary, to or for any and every original lot laid out, or to be laid out, in and by any town or proprietors .... ${ }^{178}$

176. Taylor v. Porter, 4 Hill 140, 142 (N.Y. Sup. Ct. 1843).

177. An Act for Highwayes $\S 4$ (Dec. 6, 1693), in MASSACHUSETTS LAWs, supra note 149, at $136,137$.

178. An Act in Addition to the Law of this Province, Entituled "An Act for Highways," Made in the Fifth Year of the Reign of the Late King William and Queen Mary $\S 1$ (Nov. 6, 1713), in MASSACHUSETTS LAWS, supra note 149, at 721, 721.

New Hampshire similarly directed local officials to "lay out, or cause to be laid out Particular or Private High Ways between any of the Inhabitants or Proprietors within their respective Towns...." An Act for Preserving of High Ways, and for Making such others as may be needful (May 2, 1719), reprinted in CuSHING'S NEW HAMPSHIRE LAWs, supra note 149, at 169, 170. In the event that the selectmen had not satisfactorily performed this task, New Hampshire specified that the power to create private roads would be assumed by the courts. See id. at 17071. Vermont authorized selectmen "to lay out or cause to be laid out... private ways for such town only as shall be thought necessary ...." An Act for Laying out and Altering Highways (Feb. 24, 1779), in VeRMONT LAWs, supra note 166, at 86, 86.

South Carolina's assembly did not rely on local officials, but supervised its private road regime itself. It accordingly drafted private road acts with great particularity. The Colony provided for, among many others, the construction of a private road "from the house of Mr. Thomas Elliott, jun., and also from Mr. William Elliott's, inclusive, to Mr. William Elmes's Cowpen, inclusive, and from thence to John Godfrey's landing, on Pon Pon river" on the grounds that local inhabitants were "about twelve miles distance from any public established road...." AN ACT for making a new Road between the north and middle branch of Stono River (Mar. 11, 1726), in 9 SOUTH CAROLINA LAWS, supra note 160, at 65, 65-66. 
State governments also authorized private roads by ceding the power of eminent domain to private individuals. ${ }^{179}$ Private roads of this second type were often in the form of easements, with an isolated landowner securing permission to construct an access road over the estate of his neighbor. For instance, New York allowed landowners, when it was "absolutely necessary," to lay out private roads over neighboring lands, provided that "all the expenses and charges attending the laying out and valuing the same, shall be paid by the person or persons applying for the same ....",180

Although some private roads reverted to the state upon construction, thus becoming public thoroughfares, certain others remained privately held and maintained. In 1715, North Carolina specified that all roads previously constructed under government authority, legislative or judicial, would henceforth be public:

[A]ll Roads and Ferries in this Government, already laid out or appointed, by Virtue of any Act or Ordinance of Assembly heretofore made or declared, or by Virtue of any Order of Court grounded thereon, which are or ought to be now in Use, shall be, and are hereby declared to be Public Roads and Ferries .... ${ }^{181}$

179. Rhode Island directed that "the proprietors of lands in each and every town in this State shall lay out suitable, necessary and convenient highways, within their respective proprieties, from town to town, and to mills and markets, and generally wherever they may be wanted ....” An act for laying out Highways $§ 1$ (1715), in RHODE IsLAND LAws, supra note 149 , at 286,286

180. An ACT for the better laying out, regulating and keeping in repair, all common and public highways, and private roads, in the counties of Ulster, Orange, Duchess Charlotte and Westchester, art. XII (Mar. 11, 1779) [hereinafter New York Private Road Act], in 1 LAWS OF THE STATE OF NEW YORK 1777-1784, at 127, 130-31 (1886) [hereinafter NEW YORK LAWs]. Pennsylvania similarly allowed its citizens to petition courts for permission to construct private roads over the lands of their neighbors: "[I]f it shall happen that such road shall be carried through any man's ground, the damage sustained thereby, by the owner or owners, shall be ... paid for by the person or persons at whose request the road was granted and laid out ...." An Act for laying out, making and keeping in repair, the public roads and highways within this commonwealth, and for laying out private roads $\$ 17$ (Apr. 6, 1802) [hereinafter Pennsylvania Private Road Act], reprinted in PENNSYLVANIA LAWS, supra note 152, at 792, 798.

181. An Act, concerning Roads and Ferries, art. I (Jan. 19, 1715), reprinted in 1 CusHING'S NorTh CARolina Laws, supra note 96, at 16. Delaware stipulated that "all such Roads and Cartways" constructed under colonial authority would be "deemed and allowed to be free, open and lawful Common Roads and Cartways ...." An ACT for laying out Roads, and for erecting, repairing and maintaining Bridges, Causeways and Highways within this Government (date unknown) [hereinafter Delaware Private Road Act], reprinted in CUSHING'S DELAWARE LAws, supra note 149, at 201, 207-08. Rhode Island likewise provided that private thoroughfares could, albeit at the discretion of the owner, be made into public roads:

[W]henever the owner or owners of any land, shall make a deed thereof to the town wherein such land lies, for the special purpose of being used and improved as a pub- 
New York, by contrast, expressly contemplated that the private road would become the fee simple property of the man who constructed it: "[T]he said road when so laid out, shall be for the only use of the person or persons who shall pay for the same, his heirs and assigns, but not to be converted to any other use or purpose, than that of a road." $" 182$

Commentators generally regard private road statutes as evidence that the original meaning of the "public use" language required only that a seizure of property produce a benefit to the public. ${ }^{183}$ In particular, the construction of private roads was often justified because of the public benefits they were thought to produce: aiding the nation's economic development, ${ }^{184}$ enabling the militia to assemble, ${ }^{185}$

lic highway... the said land shall be thenceforward a public highway to all intents and purposes ....

An act for laying out Highways $\S 8$ (1715), in RHODE IsLAND LAws, supra note 149, at 286, 289.

While the more common practice was for private roads to be made public, at least one colony permitted public roads to revert to private ones. In Rhode Island, a public road could become private if a town council elected to sell it ("the town-council ... shall have power and authority to sell and dispose of any such inconvenient or useless highway ... which deed or deeds so made shall create in the purchaser or purchasers thereof, a good and lawful estate in fee simple"), or to declare it useless ("whenever any road shall cease to be useful to the public, the town-council of such town shall be authorized so to declare it, and the said road shall revert to the owner"). Id. § 6, in RHODE ISLAND LAWS, supra note 149, at 289.

182. New York Private Road Act, art. XII, in NEW YORK LAWS, supra note 180, at 131. The road owner was not, however, entitled to exclude the former property owner from the road: "[T] he owner or owners of the land through which such private road may be laid, shall not be prevented from making use of such road, if he shall signify his intention of making use of the same...." Id.

Delaware prevented colonial funds from being used to repair its private roads. When it enacted a law authorizing justices of the peace to maintain "all the publick Highways, Causeways and Bridges," its assembly expressly excepted those that, "by virtue of any Act of General Assembly of this Government, or otherwise, have been or shall be laid out, made or erected for the private Interest of any Person or Persons ...." Delaware Private Road Act, reprinted in Cushing's Delaware Laws, supra note 149, at 202. Pennsylvania likewise required that owners of private roads maintain them without state assistance. See Pennsylvania Private Road Act $\S 17$ (Apr. 6, 1802), reprinted in PENNSYLVANIA LAws, supra note 149, at 798 ("[T] he said road shall be opened and kept in repair by and at the expense of the person or persons at whose request the same was granted and laid out, and of such as have occasion to travel to and from their dwelling houses on the said road ....").

183. See Berger, supra note 12, at 207 (describing this practice as "a well-developed system of condemnation for what in the narrow sense was a private use").

184. See An ACT for laying out Roads, and for erecting, repairing and maintaining Bridges, Causeways and Highways within this Government (1741-42), reprinted in CusHING's DELAWARE LAWS, supra note 149, at 201, 201 (speculating that the existing manner of maintaining roads was "very burthensome and expensive to the Inhabitants"); An act for roades to houses (Sept. 23, 1667), in 2 VIRGINIA LAWS, supra note 149, at 261, 261 ("[T] he dispatch of busines in this country is much obstructed for want of bridlewayes to the severall houses and 
and, in later years, allowing isolated citizens to exercise public duties such as voting or jury service. ${ }^{186}$ As with the Mill Acts, then, the private road acts suggest that a taking of private property need not have vested all citizens with a right of use to pass "public use" muster.

\section{REPUBLICANISM AND "PUBLIC USE"}

Given the republican principle that political power must be deployed in service of the common good, rather than of individual citizen's interests,${ }^{187}$ one might expect early American law to have abjured takings of private property that benefited an identifiable subset of the public at the expense of others. Of course, laws enacted for the advantage of one person, or group of persons, were relatively common in the republican era: so-called private laws - that is, laws enacted for the relief of individual citizens - were a regular feature of the early American legal landscape. ${ }^{188}$ But acts benefiting one group of citizens at others' expense conflicted with republican political theory, for such measures would have required the legislature to balance the competing interests of various social groups. Nevertheless, at the apogee of republicanism's influence throughout the colonial and early national periods, American lawmakers routinely authorized seizures of private property - the Mill Acts and private road acts, in particular - that directly advanced the interests of only a portion of the public. $^{189}$

plantations."); see also Berger, supra note 12, at 207 ("At a time when almost the entire country was a wilderness with practically no public roads ... the use of condemnation to open private roads from one person's land across the property of others to the public roads was a necessity if the country was to be developed at all.").

185. See Act of Feb. 12, 1719, in 9 South CAROLINA Laws, supra note 160, at 46, 46-47 ("[T]he want of convenient roads, upon all occasions, hath much prevented the uniting of our forces in the defence of this Colony ...."); Act of Feb. 5, 1705, in 9 South CAROLINA LAws, supra note 160, at 6,6 ("[T] he want of convenient ferries and roads upon all occasions, hath much prevented the uniting of her Majestie's forces in the defence of this colony ....").

186. See, e.g., Brewer v. Bowman, 9 Ga. 37, 41-42 (1850) ("[T]he establishment of private roads... is not exclusively for the benefit of the individuals upon whose application they may be so established, but that the public are also interested in every citizen having a right of way to and from his lands or residence."); Robinson v. Swope, 75 Ky. (12 Bush) 21, 25 (1876) (“[T]he general assembly may, in the exercise of the right of eminent domain, authorize the establishment of private passways over the lands of others when it is necessary to enable any inhabitant of the state to attend courts, elections, churches, or mills, or to reach an established public highway.").

187. See supra notes 54-58 and accompanying text.

188. See Charles M. Cook, The American Codification Movement 6-7 (1981)

189. See supra Part III.B-C. 
The modern eye readily perceives that such takings could be justified only under a broad public-benefit reading of the "public use" requirement, but early Americans viewed them through an ideological lens that regarded the public as an organic whole. Under republican theory, which held that all members of the public shared a uniform set of interests, ${ }^{190}$ takings that advanced the interests of one citizen could be regarded as advancing the interests of all. The resulting good would be universal, since it would advance an interest in which all members of the public participated; it also would be equal, since no one citizen stood to gain from public benefits more than any other. Hence when coupled with the republican assumption of homogenous interests, the taking would have satisfied the actual-use test.

For example, states enacting the Mill Acts contemplated that they would produce the public benefits of economic growth, development, commerce, and immigration. ${ }^{191}$ Such benefits would redound to all citizens insofar as they were citizens; all who lived in a given state stood to benefit from greater commercial opportunities, a better-developed infrastructure, or a larger population base. Furthermore, no one person stood to benefit more than any other from these goods; no one had a greater legal right to engage in commerce or to use newly built roads. For similar reasons, early Americans approved the creation of private roads. The benefits of effective militia service, widespread political participation, and economic development were public goods in which all members of the public equally participated. ${ }^{192}$

The assumed distribution of benefit among the entire public was not farfetched, and indeed it resembled a commonplace concept that justified the state's authority to punish criminal wrongdoing. According to the political science of the day, the state could punish a miscreant because the harm he caused his fellow citizen was an injury to the entire body politic. Blackstone explained that the Crown is "in all cases the proper prosecutor for every public offense" because "the king, in whom centers the majesty of the whole community, is supposed by the law to be the person injured by every infraction of the public rights belonging to that community ....." ${ }^{193}$ A crime against a

190. See supra notes 63-67 and accompanying text.

191. See supra note 158 and accompanying text.

192. See supra notes $184-86$ and accompanying text.

193. 4 BLACKSTONE, supra note 84 , at *2. 
single individual became, for the purposes of the law, a crime against the entire public to be rectified by the Crown. Thus, just as the law assumed that an injury to a single man could be spread among all citizens, it also assumed that a benefit to a discrete group could similarly be distributed among all citizens.

Republican ideology thus provides the vital context for understanding the founding generation's conception of the public that was enshrined in the Fifth Amendment's "public use" requirement. Because republican theory held that all members of the public share identical interests, it enabled adherents to regard takings that benefited only some fraction of the public as takings to the advantage of all citizens. In other words, early Americans permitted seizures of property that satisfied the public-benefit test only because, under the reigning political theory of the day, such takings could be seen as actual-use takings.

To the extent that contemporary public-benefit theory rests upon originalist grounds ${ }^{194}$ it is rooted in an inadequate historical account. Commentators who locate the original meaning of the "public use" language in the permissive practices of colonial and state legislatures fail to explain early Americans' acceptance of the public-benefit theory in light of that era's dominant ideology. In short, a fuller originalist account of the "public use" requirement is needed. The crucial question is how can-and, indeed, should-modern takings law reflect that we no longer assume that all members of the public share an homogenous set of interests?

While the resolution of this matter is beyond the scope of this Note, a few possible applications of the republican vision of "public use" come to mind. One solution would be to adapt public-use law to account for the fact that the crucial assumption of public-benefit theory has been cast off. Such an approach would involve "translating" the ancient practice of public-benefit takings into the modern era. Translation is a species of originalist analysis propounded by Professor Lawrence Lessig, who argues that when a judge construes a constitutional provision, he should identify the objective of that clause, determine which presuppositions have changed in the modern era, and accommodate that change by seeking a modern "equivalent." 195

194. See, e.g., Berger, supra note 12, at 204-08; Melton, supra note 11, at 65-80; Rubenfeld, supra note 23, at 1120-21; Stoebuck, supra note 4, at 591-95.

195. See Lawrence Lessig, Fidelity in Translation, 71 Tex. L. REV. 1165, 1263 (1993). Translation methodology has been applied in the takings context, in particular, by Professor Treanor, who advocates a political-process theory of the Takings Clause. See Treanor, Political 
An approach to constitutional interpretation commonly associated with judicial liberalism, translation may be contrasted with traditional text-based originalism, a method of conservative pedigree that focuses not on intentionalist or other subjective considerations but on the founding generation's understanding of a given textual provision. ${ }^{196}$

A "translated" account of the broad original understanding of "public use" could require that, in the modern era, a taking of private property satisfy the stricter actual-use test, whereas conventional originalism would be satisfied with retaining the public-benefit standard. Thus, liberals who generally favor relaxed "public use" scrutiny ${ }^{197}$ may be forced to resort to traditional originalism to retain the broad public-benefit test they desire, whereas conservative defenders of property rights might abandon originalism to secure a more property-friendly rule.

\section{CONCLUSION}

Modern scholars correctly perceive that public-benefit theory reflects the original understanding of the Fifth Amendment's "public use" requirement, but their accounts neglect the influence of early American political theory on that understanding. In fact, foundinggeneration Americans accepted the public-benefit test because republican ideology enabled them to regard takings to the advantage of a discrete group's interests as actually benefiting the interests of the entire body politic. Contemporary Americans no longer believe that all members of the public share the same core interests, and modern takings law must therefore consider the continuing vitality of the public-benefit theory now that that crucial assumption has been discarded.

Process, supra note 15, at 855-56.

196. See, e.g., Robert H. Bork, The Tempting of America: The Political SEDUCTION OF THE LAW 144 (1990) ("Law is a public act. Secret reservations or intentions count for nothing. All that counts is how the words used in the Constitution would have been understood at the time."); id. ("What is the meaning of a rule that judges should not change? It is the meaning understood at the time of the law's enactment."); SCALIA, supra note 113, at 38 ("What I look for in the Constitution is precisely what I look for in a statute: the original meaning of the text, not what the original draftsmen intended.").

197. See, e.g., Bruce A. ACKerman, Private Property AND the Constitution 190 n.5 (1977) ("[A]ny state purpose otherwise constitutional should qualify as sufficiently 'public' to justify a taking."). 